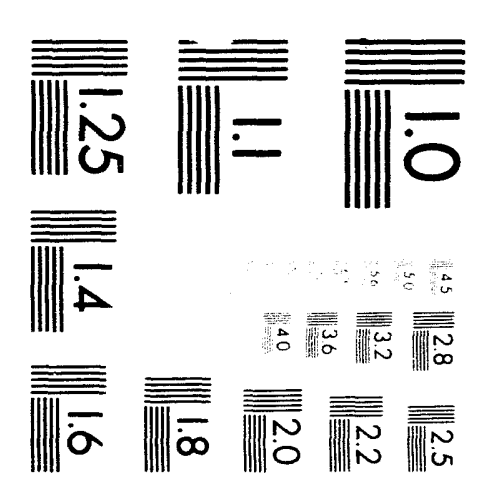



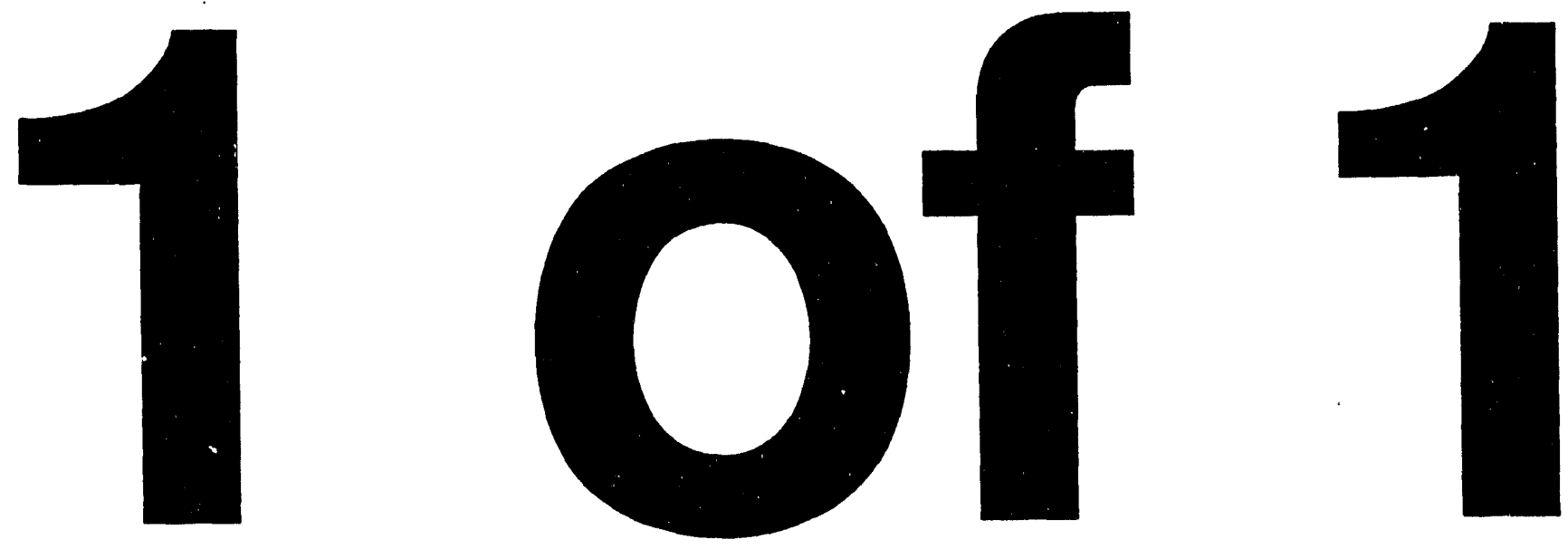
ORNL-6781

ENVIRONMENTAL SCIENCES DIVISION

\title{
BIOFUELS FEEDSTOCK DEVELOPMENT PROGRAM ANNUAL PROGRESS REPORT FOR 1992
}

\author{
L. L. Wright \\ J. H. Cushman \\ A. R. Ehrenshaft ${ }^{1}$ \\ S. B. McLaughlin \\ W. A. McNabb \\ S. A. Martin' \\ J. W. Ranney \\ G. A. Tuskan \\ A. F. Turhollow ${ }^{2}$
}

${ }^{1} \mathrm{He}$ alth Sciences Research Division

${ }^{2}$ Fnergy Division

Environmental Sciences Division

Publication No. 4196

Date Published: November 1993

Prepared for the

Office of Transportation Technologies

Biofuels Systems Division

EB 2413010

Prepared by the

OAK RIDGE NATIONAL LABORATORY

Oak Ridge, 'Tennessec 37831-6285

managed by

MARTIN MARIETTA ENERGY SYSTEMS, INC.

for the

U.S. DEPARTMENT OF ENERGY

under contract DE-AC(05-84OR21400) 


\section{CONTENTS}

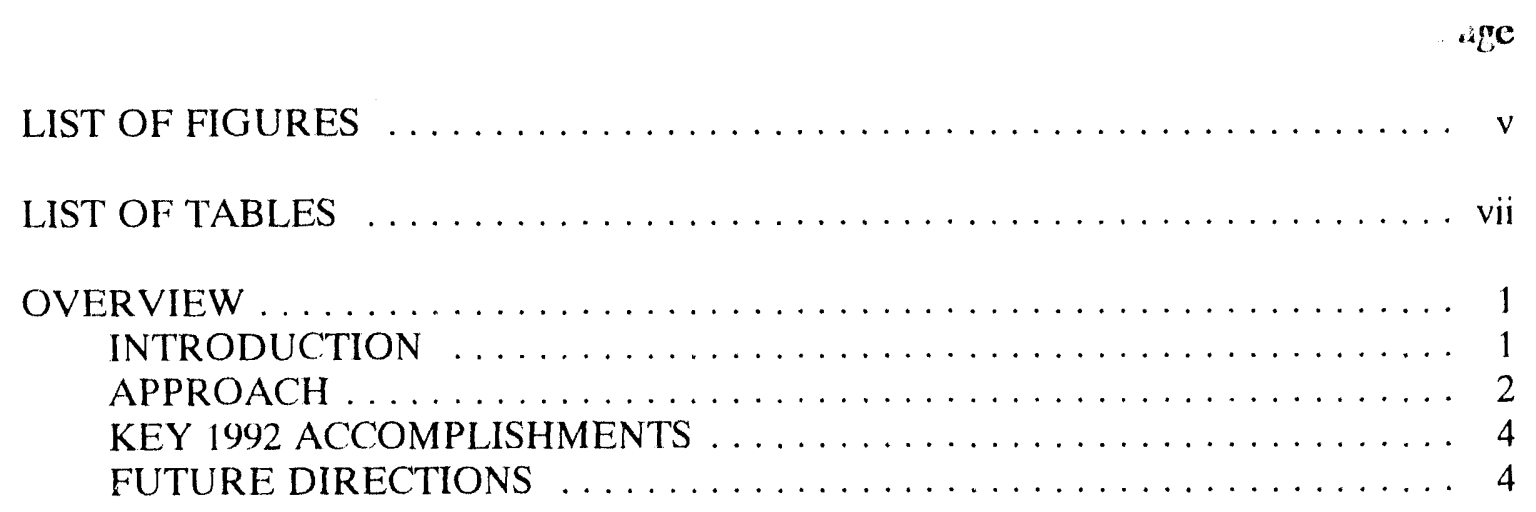

1992 RESEARCH HIGHLIGHTS AND ACCOMPLISHMENTS . . . . . . . . . 7

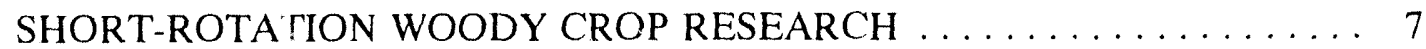

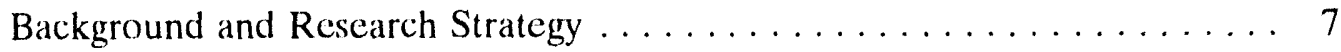

Populus Research Progress . . . . . . . . . . . . . . . . . 7

Additional SRWC Research Progress .................. 9

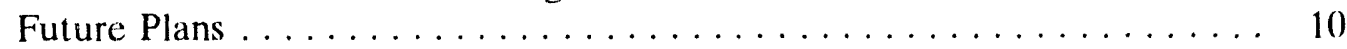

HERBACEOUS ENERGY CROPS RESEARCH ............. 11

Background and Research Strategy . . . . . . . . . . . . . 11

Summary of Preceding Cultural and Variety Selection Research

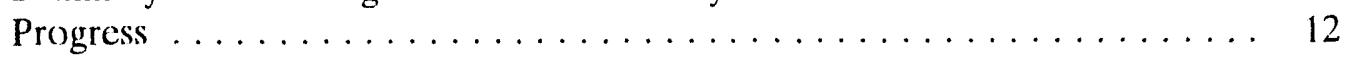

Initiation of New Rescarch Projects $\ldots \ldots \ldots \ldots \ldots \ldots \ldots \ldots \ldots \ldots$

Future Plans . . . . . . . . . . . . . . . . . . . . . 15

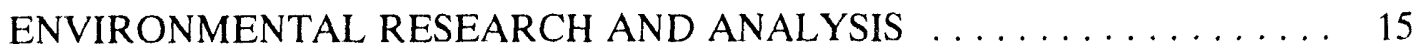

Background and Research Strategy . . . . . . . . . . . . . . 15

Environmental Research and Analysis Highlights ............. 16

Other Environmental Issues . . . . . . . . . . . . . . . . . . . . 19

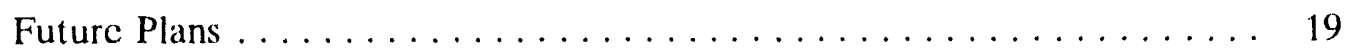

ECONOMIC ANALYSIS AND INTEGRATION $\ldots \ldots \ldots \ldots \ldots \ldots \ldots$ 20

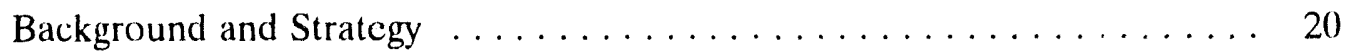

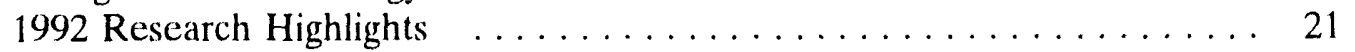

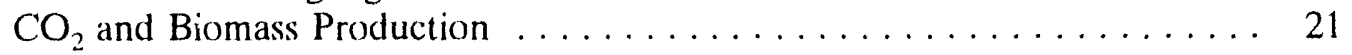

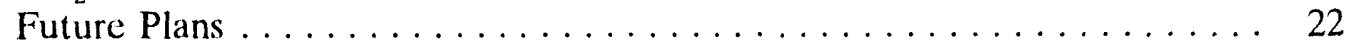

ENERGY CROP DATA AND INFORMATION MANAGEMENT . . . . . . . 25

INFORMATION MANAGEMENT ACTIVITIES $\ldots \ldots \ldots \ldots \ldots \ldots \ldots$

FUTURE DIRECTIONS $\ldots \ldots \ldots \ldots \ldots \ldots \ldots \ldots \ldots \ldots \ldots \ldots \ldots$

APPENDIX A: BIOFUELS FEEDSTOCK DEVELOPMENT PROGRAM

PROJECTS $\ldots \ldots \ldots \ldots \ldots \ldots \ldots \ldots \ldots \ldots \ldots \ldots \ldots \ldots \ldots \ldots$ 


\section{LIST OF FIGURES}

$\begin{array}{ll}\text { Figure } & \text { Page }\end{array}$

1 Methods for improving and protecting switchgrass productivity $\ldots \ldots \ldots \ldots$

2 Price of delivered $S W R C$ wood $(\$ \$ /$ dry $\mathrm{Mg}$ at power plant $) \ldots \ldots \ldots \ldots \ldots$

3 Additional transect of species censusing in hybrid poplar plantations . . . . . . . 18

4 Mockling system used to estimate national supply and environmental impacts . . . 22

$5 \mathrm{CO}_{2}$ emissions from ethanol produced from corn under varying assumptions $\ldots \ldots 23$

6 Comparison of $\mathrm{CO}_{2}$ emissions from energy crops and fossil lucls $\ldots \ldots \ldots \ldots \ldots 24$

7 Comparison of $\mathrm{CO}_{2}$ emissions from gasoline and ethanol produced from energy

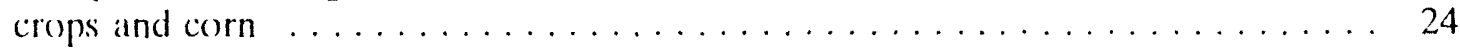




\section{LIST OF TABLES}

Table

Page

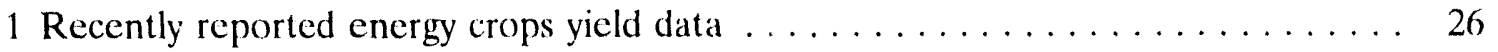




\section{OVERVIEW}

\section{INTRODUCTION}

The Department of Energy's (DOE's) Biofucls Feedstock Development Program (BFDP) leads the nation in the research, development, and demonstration of environmentally acceptable and commercially viable dedicated leedstock supply systems (DFSS). The goals of the program include technology development and technology implementation. BFDP's overriding goal is to develop a variety of dedicated biomass feedstock technologies that could supply as much as $15 \%$ (up to 20) (JJ) of the primary energy produced in the United States. A second goal is to ensure successful technology acceptance and implementation.

DFSS have the potential of providing a very large renewable source of biomass supplies for energy, fiber, and chemicals. DFSS incorporate the production of specialized tree and grass crops with appropriate systems for harvest, storage, and delivery. With appropriate technology and planning, DFSS can meet high standards of environmental quality on a wide variety of cropland types, including some types of environmentally sensitive land. Production of DFSS for energy on a large scale could provide a significant source of renewable encrgy that could enable reduced reliance on fossil fuel sources. Several evaluations of solutions for preventing or delaying global warming indicate that biomass energy must become a significant energy resource. Production of DFSS for a large energy market could revitalize the rural economy and remove some of the burden of federal subsidy payments to farmers. The BFDP has been charged by DOE with leading the research, development, and demonstration required to convert potential benefits into real benefits.

The BFDP has been managed by stall in the Environmental Sciences Division (ESD) of Oak Ridge National Laboratory (ORNL) for DOE's Biolucls Systems Division since 1978. Most of the technology research and development work has been performed by subcontractors in academic, private, and government institutions. The intormation development and technology transfer activities required for ensuring technology aceeptance has been performed by both ORNL stafl and subcontractors or cooperators. The program complements and collaborates with biomass conversion research supported by at least three different divisions and offices within DOE.

BFDP researchers have evaluated a wide variety of plants that could be used as dedicated biomass feedstocks and the types of land on which they can be produced. Numerous cropping and harvesting methods have been considered, and the production costs associated with each have been evaluated. Exciting new techniques for crop improvement and modification have been developed. The program currently eoordinates an extensive network of integrated research on crop development (Appendix 1), maintains a unique data base on crop production techniques, and performs resource and economic analysis of DFSS. The environmental implications of biomass leedstock production are being evaluated on local, national, and global scales.

The BFDP shares the responsibility of capturing the potential of biomass energy with biomass conversion research programs supported by DOE. The BFDP is most closely linked to the biomass-to-liquid fuel 
rescarch conducted by the National Renewable Encrgy Laboratory (NREL) and supported by the Biofuels Systems Division under the DOE Office of Transportation Technology. The U.S. interest in reducing oil imports places a high priority on developing biofuels.

Utility interest in biomass-to-electricity technology is expanding rapidly because of increased global warming concerns and pending regulations on $\mathrm{CO}_{2}$ emissions. Thus, the technology and information resources developed by the BFDP are also being heavily relied upon by the Solar Thermal and Biomass Power Program under the DOE Office of Utility Technologies.

A third source of interest in biomass lecdstocks is emerging within DOE:s Offiec of Industrial Technologies as programs $t o$ increasc industrial energy efliciency recognize the potential of biomass leedstocks and as new ways are lound to produce chemicals from biomass liecdstocks.

Industries interested in biomass resources indicate that dependability and reliability of biomass leedstock supplies are (wo) of their largest concerns. With biomass conversion technologies approaching demonstration phases, with global environmental concerns accelerating, and with farmers searching lor new crops and markets, the importance of the research managed by the BFDP is expected to increase dramatically. The past 14 years of research management has given ORNL the experience and knowledge needed for leading a well-focused effort in converting the potential of biomass energy to a reality.

\section{APPROACH}

The BFDP provides kadership in the development of DFSS in the following ways. It integrates agriculture, energy, and environmental objectives in developing concepts of integrated biomass energy systems. It seeks and fosters the best research, development, and demonstration projects in the private, academic and government sectors. It strives 10 ensure that information on biomass supply systems is timely, accurate, understandable, and accessible.

The BFDP has organized its research, analysis, and management resources 10 meet near-term needs and to prepare for future expectations. Rescarch in 1992 was conducted under live task areas including woody crop development, herbaceous crop development, environmental research and analysis, economic analysis and integration, and information management. Each task keader managed a mixture of subeontracts, supervised internal work, and conducted relevant individual research and analysis. All of the efforts have been focused on facilitating the commercialization of integrated, environmentally sound, biomass encrgy systems.

The woody and herbaceous crop tasks both have three key deliverables: development of (1) plant culture technologies, (2) appropriate, superior plant materials, and (3) developed germplasm resources. Research is currently being focused on two general regions, the north ecentral/midwest region and the south/southeast region for the development of superior plant materials, germ-plasm resources, and cropping systems technology. Other technologies such as tools for genetic manipulation and improvement, site quality/site index prediction functions, vegetative propagation techniques, and physiological characterization of root growth are being developed at specific locations with generic application to any region of the United States. The current program strategy is to develop new varicties of switchgrass and new clones of poplars for the north central/Midwest and the South/Southeast regions. Two breeding centers for 
switchgrass currently exist-Oklahoma State University and the USDA Agricultural Rescarch Service at Lincoln, Nebraska. The breeding centers are assembling hreeding materials and developing superior secd sources for evaluation by collaborators. Collaborators are concentrating on testing currently available varictics, improving agronomic techniques, and developing tissue culture techniques. Two breeding centers for Populus also) exist, and a third is being planned in FY 1993. The oldest center is led by the University of Washington in collaboration with Washington State University and industry collaborators. The newer center is led by lowa State University in collaboration with several other universitics. The Populus breeding centers involve integrated crop research connected with a breeding program focussed on assembling breeding materials, developing superior pedigrees, and releasing clones for widespread testing. The connected supportive Popules research consists of applicable physiology, molecular biology, pathology, entomology, and silviculture. These crop development strategies should result in prompt, cost-eflective gains in research knowledge as well as production of the deliverables noted above for switchgrass and Populus. Crop development centers for additional species need to be established but are not planned at this time.

The BFDP economic and environmental tasks are closely linked. The key deliverables of these tasks are to (1) deline energy crop price-quantity relationships, (2) identify and document the ecologically important and environmentally regulated effects of biomass commercialization, and (3) bring these efforts together to address citing issues and define viable ways to optimize environmental benefits within economic constraints. Data collection and analysis aimed at predicting potential environmental and economic changes (positive and negative) resulting from commercialization of energy crop production is gaining more attention. The economic and environmental tasks also include the development of concepts of integrated biomass energy systems that could contribute to the successful demonstration of integrated biomass energy systems. These concepts are being developed in close linkage among (1) researchers from NREL working on both liquid fuel and biomass electric technologies, (2) analysts from the Electric Power Research Institute and individual utilities, (3) environmental groups such as the Audubon Society and the Nature Conservancy, (4) tiber leedstock production managers in the wood products industry, and (5) managers of similar research programs in other parts of the world. The linkages are oecurring through cost-shared research, presentations at workshops and meetings, roundtable discussions, data and information exchange, and site visits. This dialogue with diverse interested parties is considered necessary at this lime to ensure that the broadest public interest is considered in the development of biomass energy technology.

The BFDP information management lask has a vital role in meeting customer needs for research information on energy crop systems. Better information management and tracking systems are being developed. Other information centers are being evaluated as models for enhancing our technology transfer efforts. The newsletter, Energy Crops Fonum, being produced by the intormation task leader is lacilitating the necessary communication among energy crop researchers, potential energy crop producers, and potential energy crop users. 


\section{KEY 1992 ACCOMPLISHMENTS}

The purpose of this report is to highlight the status and aceomplishments of the research that is currently being funded by the BFDP. Highlights summarized here and additional accomplishments are described in more detail in the sections associaled with each major program task. A low key accomplishments include

1. Development of a methodology for doing a cost-supply analysis for energy crops and the application of that methodology to looking at possible land use changes around a specilic energy lacility in East Tennessec.

2. Preliminary documentation of the relationship between woody crop plantation focations and bird diversity at sites in the Midwest, Canadat, and the Pacifie Northwest supplied indications that woody crop plantations could be benelicial to biodiversity.

3. Receipt of a $\$ 150,(0)()$ per year grant from the DOE/National Science Foundation (NSF)/U.S. Department of Agriculture (USDA) Joint Program on Collaborative Research in Biology by BFDP subcontractor, University of Washington, which will allow completion of a genetic linkage map for poplar clones developed with BFDP funding.

4. An award of a 3-year, $\$ 200,0000$ per year grant was received by ESD stall for the purpose of introducing plant hormones into hybrid poplar in an effort to enhance Populus feedstock quality. This work was made feasible by the investment of the BFDP program in the capital equipment neecied to make an ESD biotechnology research laboratory operational.

5. The initiation of integrated switchgrass variety trials, hreeding rescarch, and hiotechnology rescarch for the south/southeast region.

6. Development of a data hase management system for documenting the results of herbaceous energy crop lick trials.

7. Publication of three issues of Energy Crops Forrum and development of a readership of over 2300 individuals of organizations as determined by positive responses on questionnaires.

\section{FUTURE DIRECTIONS}

The BFDP is undergoing ensiderable change in emphasis and direction. Numerous integration analysis and technology transler activities have been added to the program without any increase in lunding. Changes required 10 accommodate this adjustment are as (ollows.

- Nearly all of the species and silvicultural screening trials for both woody and herbaceous species have heen brought to a close.

- Linked physiology/breeding studies for all woody crops other than poplars are also being brought to a close in 1993 or 1994.

- Crop development efforts will concentrate on poplars and switchgrass and may include a new cost-shared breeding effort for woody crops for the South/Southeast. 
- Ongoing work in economic and environmental analysis will be expanded and combined together under a new task called "Systems Integration and Analysis." Work will include fucl cycle analysis and risk assessments.

- Geographic information systems (GIS) will be used to address landscape ecology issues.

- The "Environmental Research" task will concentrate on collecting data needed for evaluating environmental effects of DFSS and for improving the environmental soundness of DFSS.

- ORNL researchers will determine the feasibility of genetically altering the composition of energy crops to enhance the efficiency of conversion processes.

- Additional effort will be put into organizing and documenting the unique information resources of BFDP to make them more accessible and available for use by a wide variety of interested customers. The program strives to be responsive to current needs while continuing to support the high-quality, long-term research efforts required in the development of new crops.

Many additional research, development, integration, and demonstration needs are recognized by the program but cannot currently be met under anticipated budgets. A few of these needs are

- Initiation of a few biofucls systems demonstrations and development of site-specific guidelines for best crop management techniques.

- Expansion of environmental rescarch on biodiversity, sustainability, and landscape ecology to develop environmentally sound crop production techniques.

- Creation of an energy crop information center, integrated with NREL, to facilitate getting research information to extension networks, energy producers, and larmers.

- Cration of extension networks through traditional USDA channels for getting information to potential feedstock producers.

- Development of lower-cost harvest, handling, and transportation options for energy crops through systems modeling and new equipment development.

- Initiation of crop improvement programs with a greater varicty of crops and in a greater number of locations.

- Expansion of plant sciences rescarch on topies such as drought and pest tolerance, photosynthesis, and genetic moditication of plants.

A major BFDP effort in FY 1993 will include articulating more clearly what needs to be done, suggesting logical avenues for pursuing the efforts, and working to expand the impact of the program through cooperative efforts with both public and private organizations. 


\section{RESEARCH HIGHLIGHTS AND ACCOMPLISHMENTS}

\section{SHORT-ROTATION WOODY CROP RESEARCH}

\section{Background and Research Stratcgy}

Dedicated wood energy crops generally consist of deciduous hardwood tree species that have been selected for qualities suitable for biofuels conversion, such as rapid carly growth, pest resistance, broad general adaptability, high cellulose content, and the ability to regenerate via coppice sprouts. Historically, research in the BFDP has involved breeding and genetic improvement, physiological characterization, cultural management testing, and cultivar/clone site trials for several model species. Through this research, dry average yields in some regions of the United States have increased

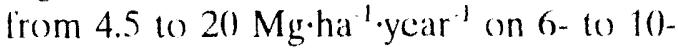
year rotations, and end-use costs have decreased from $\$ 4.00$ to $\$ 3.10$ per GJ.

There are currently 13 ongoing shortrotation woody crops (SRWC) research projects within the BFDP. These projects are designed to develop specialized wood energy crops for the regions of the United States where land availability and climate are favorable for the establishment of biomass-based energy industry. In the past. four model species have been selected for rescarch and development based on their potential to be highly productive on a broad range of sites under environmentally sound management practices and wood quality characteristics suitable for economical conversion to liquid fucks. Because of budgetary reductions, the scheduled closing of several projects, and a slight redirecting of several projects, the majority of the SRWC research in FY 1992 has dealt with Populus.
Although much is known about the Populus genus, opportunities exist for improved productivity, energy qualities, and adaptability to site variation and environmental stresses. To achieve these goals, selection and breeding based on traditional tree breeding criteria have been used to provide immediate gains, while physiological research in association with biotechnology has been used to delincate traits for long-term improvement of Populus sfecics as encrgy fecdstocks.

\section{Populus Rescarch Progress}

Several separate but connected activities were completed or initiated in FY 1992 related to Populus improvement and crop development. Two of these accomplishments primarily involve in-house activities, two primarily involve

subcontracted activities, and two others involve multiple agency activities. These six activities reflect (1) a greater emphasis being placed upon Populus improvement and crop development by the BFDP and (2) a larger effort by the BFDP to integrate existing in-house and subcontracted research.

In-house, ESD's biotechnology laboratory is now operational as a result of DOE capital equipment investments over the last 2 years. The purpose of this laboratory is to integrate the techniques of plant tissue culture, DNA isolation and characterization, and genetic transformation into existing, ongoing research activities related to SRWC improvement. As a result of these investments, the BFDP received a 3-year, $\$ 200,000$ per year grant through the Laboratory Director's Research and 
Development funds to introduce plant hormones genes into hybrid poplar in an effort to enhance Populus feedstock quality.

The second in-house activity involves the completion of the physiological and hiochemical evaluation of drought tolerance in hybrid poplars. Through the use of a six-clone pedigree, developed as part of the BFDP activity at the University (f) Washington, drought tolerance via osmotic adjustment as been demonstrated in hybrid poplar. In this pedigree, water stress-tolerant clones under stress were able to grow at a rate of $\sim 55 \%$ of wellwatered plants, compared with intolerant clones, which grew at $-45 \%$ of wellwatered plants. Pressure volume analysis indicates that water stress-tolerant clones show an osmotic adjustment of $0.25 \mathrm{MPa}$ not seen in the intolerant clones. Two separate manuscripts and a possible joint experiment with the University of Washington/Boise Cascade in eastern Washington have resulted from this work. A study with the U.S. Forest Service in Grand Rapids to examine the relationship between plantation productivity and soil and climatic characteristics in the north-central region was completed. Soil and climatic condition varied greatly across the plantation network. Of all the climatic data examined, cooling degree days was found to be significantly related to tree biomass, based on a curvilinear model. The validity of this model was supported by the below average growth witnessed in all poplar plantings in the north-central region under this summer's cooler than average growing conditions. Unexpectedly, soils data were generally not related to tree growth. Depth to water table, however, was weakly related to tree biomass. Future analyses will have to be conducted hefore soils information is excluded as a factor influencing poplar productivity.
Iowa State University has completed its 1992 evaluations of the 1991 entries in a nursery screening study. In total, 74 clones were screened for leal discases, insect leeding preference, growth ratc, branching habit, and rooting success. The best elones in terms of growth rate were pure $P$. deltoides; the best hybrid clone was a $P$. maximowiczii $x$ P. nigra. All clones in the 1991 screening trial will be sereened again in 1993 in larger clonal blocks belore the poorer performing clones are eliminated. After the second screening, the better clones will be released into small regional screening trials to identify the top $1-2 \%$ of the clones for release into operational lesting. A total of 42 clones from the 1990) larger clonal block test have been released into the small regional screcning trials.

The University of Washing!on, along with numerous collaborators, has been awarded a 3-year, \$150,(00) per year grant from the DOE/NSF/USDA Joint Program on Collaborative Rescarch in Plant Biolongy to coordinate the molecular genetics research on Populus. As a result of this award, the University of Washington will coordinate the completion of a genetic linkage map for Populus, disseminate information and plant materials ${ }^{\circ}$ researchers, and lacilitate the integration of rescarch results. These activities will benclit the BFDP at no cost by expanding the network of rescarchers studying on the Populus pedigree developed with BFDP lunding.

The second multiagency activity involves the formation of the NorthCentral Populus Research Consortium. The purpose of this consortium is to integrate Populus rescarch activitics that are currently taking place in the northcentral region in an cflort to remove duplication and to increase research output per unit dollar invested. There are 5 research agencies and 12 rescarchers 
involved in the consortium. The first year's activity involved the exchange of collected germ plasm and the coupling of the breeding research with the laboratory and field testing research. A second meeting is scheduled for early FY 1993 to set consortium objectives for the upcoming year.

\section{Additional SRWC Research Progress}

As has been shown in other countries, research solely on a single species invites failure and limited application of results. Thus, continued research related to the genetic improvement of a minimum of two model species for each of the four major short-rotation energy crops regions in the United States remains critical to the successful implementation of a national biomass program for liquid fuels production. This effort, however, remains unfunded. The following summaries report on the four remaining SRWC species under investigation by the BFDP in FY 1992.

\section{Genetic variation in silver maple} (Southern Illinois University). Four tissueculture propagated silver maple provenance lield tests have been established in three midwest states; two in 1991 and two in 1992. Clones in these tests represent 4 genotypes from 15 different provenances from across the natural range of silver maple. Each field test contains five replications of four tree plots for each selected clone. First-year survival at all sites was high, averaging $85^{\circ} \%$ at each site. The high survival rate is attributed, in part, to the use of 1.25 -mil polyethylene mulch within the plantings. Soil moisture condition remained high, and weed competition was eliminated as a result of this mulch. At the end of the lirst growing scason, the best clonc within the best provenance reached an average height of $2.3 \mathrm{~m}$ in two growing seasons, more than doubling the average growth for nonselected silver maple seedlings. Deer browsing within the plantalions has been successfully controlled through the use of a three-dimensional deer fence.

Willow monoculture viability thial (State University of New York). The BFDP began participating in a monoculture viability trial with State University of New York (SUNY). SUNY is coordinating efforts to establish two 100 -acre hybrid willow demonstration farms. This is a cooperative effort involving Electric Power Research Institute, Empire State Electric Energy Research Cooperation, Niagara Mohawk Power Corporation, New York Electric and Gas Corporation, New York State Electric Research and Development Agency, and the University of Toronto. The silvicultural system used in these farms will be modeled after the Swedish system of 3- to 4-year rotations, twin-row planting, coppice regeneration, and mechanical harvesting. Clonal material and site selection for the first 10)(-acre plantation have been completed; nursery scale-up and site preparation will continue in FY 1993.

Early selection and clonal propagation of sycamore (Mississippi State University). Dry weight yields in a 3 -year-old clonal sycamore planting have been analyzed. Average aboveground dry weight was 12.8 dry $\mathrm{Mg} \cdot \mathrm{ha}^{-1} \mathrm{year}^{-1}$ (44\% of the total tree dry weight). Total tree dry weights have been partitioned among the component parts, with $40 \%$ of the lixed carbon occurring belowground; half of this dry weight oceurred as tine roots. Early selection statistics indicated that 7-month seedling variables such as height and ground-line diameter can be used $(0)$ predict 2-year lield performance. Further data is needed to test rotation age correlations before final recommendation 
can be made. Rooted cutting experiments have been completed. Hardwood cuttings taken before bud break from 2-year-old sprouts produced the greatest height (desirable), diameter (desirable), root length (desirable), and mean sprout number (undesirable). Apomixis (i.e., the formation of viable seed in isolated, nonpollinated flowers) is being investigated and verified by genetic fingerprinting techniques. If valid, apomixis may prove to be the most reliable, useful method of vegetatively propagating mature sycamore genotypes.

Genetic improvement of black locust (University of Georgia). Third-and fourth-year field measurements have been obtained from the irrigated, fertilized, north eentral Georgia progeny test containing 24 open-pollinated families of black locust. The best family in the best plots produced 8 dry $\mathrm{Mg} \cdot \mathrm{ha}^{-1}$.year ${ }^{-1}$. Procedures for obtaining rooted cuttings have been established, with greenwood cuttings dipped for $5 \mathrm{~s}$ in $80(0) 0^{+} \mathrm{ppm}$ IBA and placed in Oasis rooting medium under intermittent mist producing $80 \%$ or higher rooting suceess across 23 different clones. Somatic embryogenic cultures have been established from excised immature embryos placed on WPM with $3 \mathrm{mg} / \mathrm{L}$ 2.4-D and $0.25 \mathrm{mg} / \mathrm{L} \mathrm{BA}$. The somatic embryogenic cultures have been used in gene transformation experiments. Biolistic transformation techniques have led to transient expression of two selectable marker genes, NPT II and GUS. Ultimately, stable transformation involving stem borer-resistance gunes will be the long-term goal of this rescarch.

\section{Future Plans}

The long-term health and security of a renewable, dedicated biomass energy crop industry will depend on actions taken today. As commercialization approaches, the BFDP SRWC research mission needs to provide those agencies, institutions, and/or corporations interested in commercialization with three deliverables:

(1) developed silviculture technologies; (2) appropriate, superior plant materials; and (3) developed germ plasm resources. Developed technologies would include systems for genetic manipulation and improvement, silvicultural systems, harvesting systems, etc. Appropriate plant materials would include adapted, highyielding, pest-resistant, environmentally stable clones. Developed germ plasm resources would include broad, systematically selected, managed collections of species' germ plasm. Short-term, crisisdriven research approaches will not allow this to happen, regardless of how appropriate or necessary these short-term approaches are.

A desirable approach to achieving these deliverables would involve restructuring SRWC research into seven centers of crop development, three for Populus and four for alternate species such sycamore, silver maple, black locust, and Salix. These centers would engage in integrated crop research focussed around a breeding program that focuses on genotype assembly, pedigree development, and clonal release. The associated, supportive research would consist of applicable physiology, molecular hiology, pathology, entomology, and silviculture. This research approach would not only lead to the requisite deliverables but should also result in the fastest, most cost-eflective gain in terms of understanding these processess. Currently, two such centers exist, with a third planned for Populus in FY 1993. No crop development eenters for species other than Populus are currently being funded by the BFDP.

Anticipated accomplishments with poplars include the development of insectand discase-resistant poplars. This 
research will remain a high priority through 1996, when a set of new clones will be identified based on greenhouse and nursery studies. Field testing of the clones should result in public release throughout 1998 to 20(12. It is anticipated that selection of superior Populas hybrids will be possible based on molecular marker-assisted selection. Early selection criteria based on physiological parameters will also be available to poplar breeders by 1996. Increased emphasis on selecting and breeding poplar clones for high yiclds under less than optimum soil and climatic conditions will be required to ensure that SRWC can potentially supply significant quantities of energy to the United States. With the initiation of the woody crop breeding program in the Southeast, it is anticipated that new plant materials may be available by $20(12$. With accelerated breeding efforts in all regions, it is anticipated that superior selections would be capable of producing 22 dry $\mathrm{Mg}_{\mathrm{g}} \mathrm{ha}^{-1}$. $\mathrm{yr}^{-1}$ under optimum conditions and 1 (o) 6 dry $\mathrm{Mg} \cdot \mathrm{ha} \mathrm{a}^{-1} \cdot \mathrm{yr}^{-1}$ under average conditions.

In addition to the Crop Development Centers, the SRWC research will need to support short-term task-specific projects that (1) need not be duplicated in each center, (2) have broad application, or (3) are exploratory in nature. The following list includes some of the anticipated task-specific areas lor which projects should be initiated.

- Development of site quality/site index prediction functions for poplars in the Midwest and elsewhere in the United States.

- Vegetative propagation of selected sycamore genotypes, including examination of apomixis as a mechanism of clonal propagation.

- Physiological characterization of belowground (i.c., root) growth, specifically related to adaptation to stress.

- Continue kesting and development of stem borer resistance in black locust through the use of biolistic gene transformation techniques.

\section{HERBACEOUS ENERGY CROPS RESEARCH}

\section{Background and Rescarch Strategy}

Research on the biofuels potential of herbaceous crops has developed much more recently than has that for woody crops. The objectives have been very similar in some respects with a common emphasis on high-yiclding crops that can be grown economically over a wide area with minimum adverse effect on the environment. Although herbaceous crops do not currently provide quite as wide a spectrum of product endpoints as worody crops do, their very high productivity, high adaptability, and landowner compatibility provide important incentives for their incorporation into the BFDP.

In 1984, a series of ten herbaceous rescarch projects began at widespread lecations across the castern and midwestern United States. A total of 35 species was examined in these initial screcning studies, which were designed to examine yield potential, biochemical composition, and rest management practices across a wide diversity of sites. The completion of several of these studies and the cxamination of data on yield potential, production economics, and regional site potential, led in 1991 to the selection of a perennial forage grass, switchgrass (Panicum lingratum), as a model species for further research.

The rationale for selection of a single species wats to concentrate and thereby improve the overall efficiency of the many 
interrelated aspects of research that were seen as requisite for biofuels production. Although more than one species will certainly be required ultimately, switchgrass was seen as an excellent beginning with the available programmatic resources.

The selection of switchgrass as a model species was based on several important considerations. As a widely adapted endemic species of the tall grass prairies, switchgrass has demonstrated a capacity for high yiclds on relatively poor quality sites. Maximum yields on test plots in Auburn, Alabama, have been 33 dry Mg.hat $a^{-1}$ year ${ }^{-1}$, well above the production level considered prerequisite for a successful biofucls industry. A large and deep root system is the key to high production and soil improvement on poor quality sites. Rescarch at Virginia Polytechnic Institute and State University has shown that soil organic carbon was increased by $30 \%$ during a 4 -year cycle, irdicating that switchgrass ha; a significant capacity to improve soil quality by sequestering carbon belowground. Improved erosion control, reduced fertilizer and pesticide requirements, and a capacity for providing wildlife cover are additional positive environmental attributes. An important quality of switchgrass is its strong potential appeal to landowness, for whom cultivation of a perennial crop that can be grown, harvested, and stored with conventional equipment represents an easy interlace with current agricultural practices.

\section{Summary of Preceding Cultural and Varicty Selection Research Progress}

During the past year, research on herbaceous biofucls crops has included the completion of species screening and productivity research (at Auburn University and the University of Kentucky) and the continuation of three projects designed to evaluate cultural and genetic attributes of predominantly perennial grass species and associated cultural practices for the upper Midwest (at USDA Lincoln, North-Dakota State, and Iowa State).

A review of the past 7 years of herbaceous crop screening research, some of which will be completed during the current year, reveals several significant measures of progress. A summary of progress in productivity research that has resulted from this work is provided in Fig. 1. It generalizes the relative improvement of yields or establishment success in research plots with various cultural treatments and/or sclection procedures. Obviously, these improvements do not have linear additive potential in terms of linal yield altained, but do demonstrate on a relative scale gains that can be made through productivity research. Most rotable are the yield improvements $(110 \%)$ made in the choice of our initial principal switchgrass cultivar, Cave-in-Rock, compared with average yields for hay, and the further improvement (180\%) made with selection of the highest-yielding variety to date, Alamo. Site quality, harvest frequency, and weed control all have been shown to be important factors in promoting or protecting switchgrass yiclds. Nitrogen fertilization to date has been effective only on poorer quality sites with typically little or no effect at levels above $70 \mathrm{Kg} / \mathrm{ha}$. On more fertile sites, effects have typically been negative to neutral. Nitrogen use efficiency and its relationship to root/rhizosphere function remains an area of future interest and utility for ecological/economic interactions.

Plant breeding represents the only approach not previously used within the program. In previous grass breeding research, genetic gain in yield has been - 5\% per cycle. Test of genetic variability in yield and in biochemical constituents known to be related to foliar nutritional 


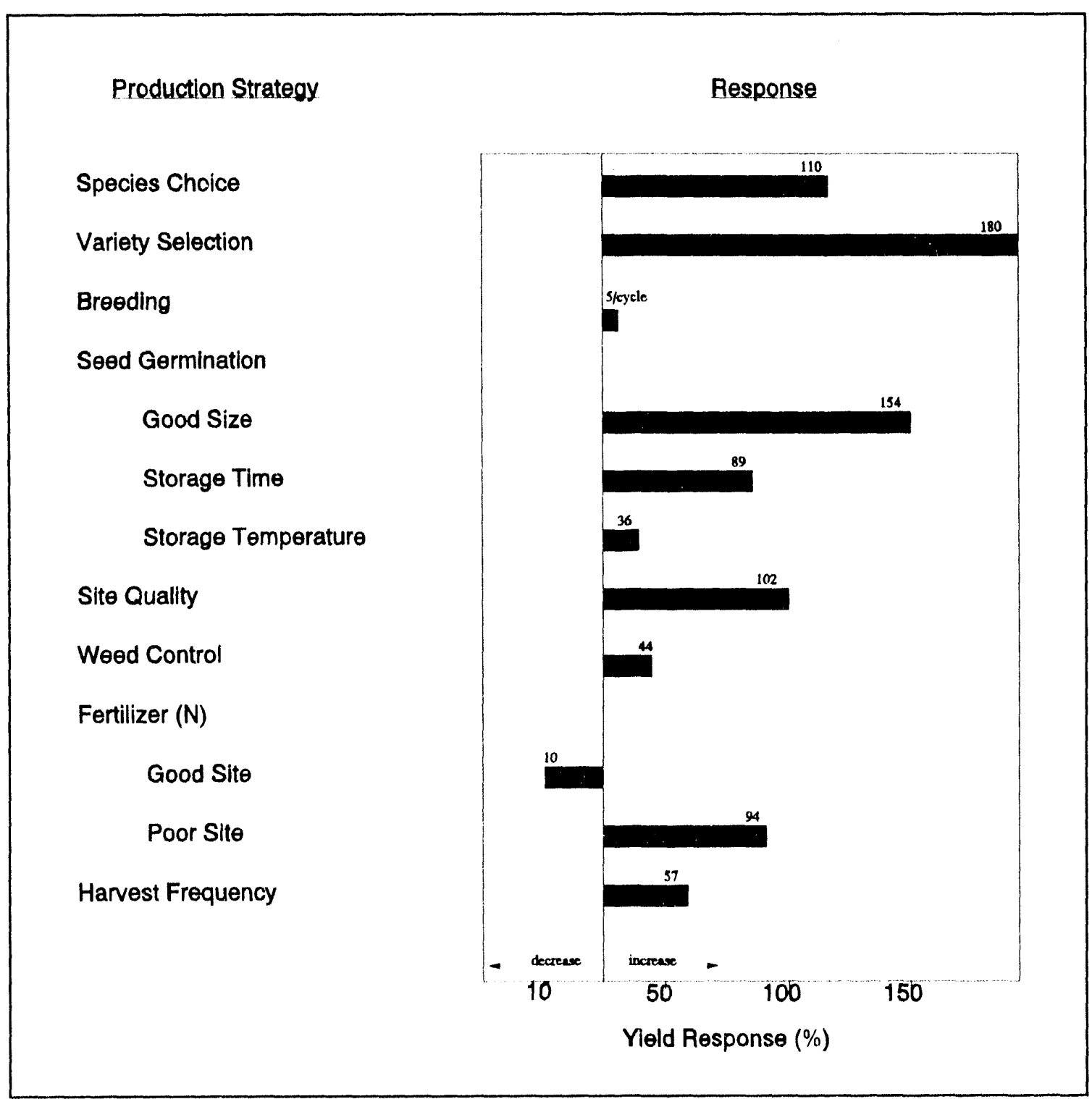

Fig.1. Methods for improving and protecting switchgrass productivity.

value of switchgrass for cattle have been evaluated within the program as a basis of future breeding effort. Significant genetic differences in tissue biochemical content have been found across 23 wild accessions of switchgrass and in 20 developed cultivars. Such information may form the basis of future breeding efforts to select for both yield mass and quality. The utility of several of these nutritive indicators for ethanol yicld is currently being evaluated in a collaborative project with NREL biochemists.

Overall, the initial species screening studies provided the data on which to select the model perennial species, switchgrass, for further programmatic emphasis. In addition, several other promising species were identified, including sorghum and sorghum-sudangrass for the Midwest and tropical grasses for the deep South. The remaining research in this 
initial screening effort will be completed in three projects in the upper Midwest during the current year. These sites include North Dakota State, Iowa State, and the USDA-ARS site at Lincoln, Nebraska.

The new research described in the following subsections builds heavily on progress made in these and other firstphase screening work.

Important logistical aspects of switchgrass production and handling relative to its use as in biofuels production were also evaluated during the past year. A collaborative study between Purdue University and NREL led to important estimates of the integrity of switchgrass bales under long-term storage pratetices. Their estimate of a very low $5 \%$ loss rate over 10 months (with proper storage conditions) provides encouraging indications of more flexible supply/demand relations for this seasonal perennial crop.

\section{Initiation of New Research Projects}

With the release of a Request for Proposals in November of 1901 , the process of building on and extending the results obtained during the first research phase began. Important findings from the carlier research that aided in the focus of this new research included the following: (1) sclection of best-yickling varieties. (2) estimates of consistency of high yields across soil types and climatic conditions.

(3) optimization of fertilization responses and harvesting strategies, and (4) quantification of impacts on soil erosion and soil organic matter. Six new projects were selected by March of 1992 with a focus that was divided between near-term, production-oriented rescarch on the best available varieties and the longerlerm breeding, physiology, and biotechnology requirements for protecting and improving future yields. Collectively, these six new research projects combine both near-term production $r$ each with longer-term development needs in an approximate $3: 2$ ratio.

The six new research projects included three regional field trials to verify and improve yield potential of selected cultivars, a breeding project to search for new improved varieties, a physiology project to develop indiecs of yield potential, and a tissue culture project to develop advanced techniques for plant propagation. Progress in each of these areas is highlighted below.

\section{Regional ficld trials and cultural} improvements. Three projects, at Virginia Polytechric Institute, Auburn University. and Texas A\&M University, were selected to represent. respectively the mid-Allantic, Southeast, and southeentral subregions of the targeled southern United States. A total of is of the planned 19 tield sites for switchgrass variety evaluations were established in 1992. Research on establishment techniques, lertilization requirements, cultural management, and harvesting strategies are important components of this rescarch. In addition, at most sites initial soil characterization will allow measurement of changes in soil nutrient status, including soil organic: carbon, over time.

Plant breeding. A single project at Oklahoma State University was selected for efforts to improve existing lines of switchgrass for biomass potential. Initial efforts are focusing on breeding across four populations representing upland and lowland ecotypes. Both hexaploid and tetraploid genotypes are represented within each ecotype. A new detached culm technique has been successfully tested for swilchgrass for the first time in this work and has allowed the lirst of three breeding cycles of Recurrent Restricted Phenotypic Selection to be completed in the lirst growing season. A switchgrass nursery has 
been established, with 6.3 accessions having heen obtained to date from several sources.

Physiology. Plant physiological studies are centered at ORNL and emphasize the development of physiological indicators for selection and evaluation of superior plant growth potential. To date, measurements of foliar gas exchange, photosynthesis and dark respiration, and biomass partitioning have been used in greenhouse studies. These indicators have been used to contrast the carbon gain potential of six upland and six lowland ecotypes over two cutting cycles. A lack of signilicant differences among genotypes under these conditions suggested that genotype-site adaptation in the field plays a very important role in yicld potential and will kead to increased emphasis on parallel physiological evaluation in field studies during the upcoming season.

Tissue culture studies. Tissue culture studies begun at The University of Tennessee in July of 1992 have already achicesel remarkable suceess. Although no formal procedures had developed for producing switchgrass from tissue culture before the project began, a variety of lechnicuess for producing switchgrass callus have already heen sucessifully tested. Node culture, shoot culture, and mature embrye culture of two cultivars have all heen shown to produce callus tissue from which seedlings have been regenerated. Flower production from callus, in onc casc, has provided some indication that tissue cullure systems for sclection as well ats propagation may be an important tool in future switchgrass yich improvement rescarch.

\section{Future Plans}

The new switchgrass rescarch projects offer some exciting challenges for integrating production, brecding, propagation, and physiology research in the future. As newly established rescarch plots across the Southeast move into their more productive postestablishment years, the associated hasic and applied research on yield limiting factors will increase the amount of information gained from these studies. Opportunities for integrating physiology, brecding,and tissuc culture techniques will increase as breeding cycles are applied and propagation technicues increase available test material for selection and validation. In parallel with the southeastern research, plans are under way (o) extend research with the USDAARS research team at Lincoln, Nebraska, to develop parallel ongoing research for the upper Midwest. This will probably include establishment, management, cytogenetic, and breeding research.

In addition 10 production-oriented rescarch, it has become increasingly clear that interfacing available production kechniques with landowner prederences will be a critical consideration for development of the technology. Both a landowner survey and a regional case study of land and harvesting strategies will be completed during the coming year to help identify and consider the important links between herbaccous biofucls production, landowner opinions, and current agricultural systems.

\section{ENVIRONMENTAL, RESEARCH AND ANALYSIS}

\section{Background and Rescarch Strategy}

ORNL has proactively pursued the quantification of environmental implications of DFSS. Areas of evaluation include hiomass production, harvest, delivery, and storage. Concerns and opportunitics fall into three major categories: emissions, sustainability, and biodiversity. ORNL is pursuing collaborative inquiries with environmental 
groups, business, regulatory grou ' other research institutions alike to document environmental benefits and resolve environmental issues before they become problems.

The Electric Power Rescarch Institute, the National Wood Energy Association, the National Audubon Society, NREL, DOE, and the U.S. Environmental Protection Agency all agree that if biofuels are to contribute more than several gigajoules of energy, the use of dedicated cellulosic crops will be necessary. This may involve tens of millions of hectares of agricultural land. Consequently, much of ORNL's analysis effort is concentrated on understanding the environmental effects of energy crop deployment.

Full biomass energy fuel cycle analyses in which ORNI. has participated indicate that the major environmental benefits and risks associated with energy crop production stem from agricultural land use change. The rapid development of a biomass energy industry could also lead to concerns about excessive forest harvesting, agricultural and forest residue utilization (heyond sustainable limits), energy conversion facility emissions, and water quality impacts. Analogies to biofucl systems are scarce. DFSS based on energy crops differ from both traditional agriculture and forestry practices, and cellulosic biofuel conversion lacility technologies are different in many respects from pulp and paper facilities. Woodburning utilities that already exist are a poor analogy for the more ceflicient biomass systems that are likely to be commercialized in the future. Comparison of the possible environmental risks of bionergy systems with the known environmental risks of fossil fuel systems indicate that responsibly implemented biomass energy systems can offer significant benelits.

In FY 1992 and into FY 1993, ORNL. has targeted rescarch efforts in three areas.
The first addresses how energy crops may compete for agricultural land and what condition that land is in. This is necessary to understand the environmental implications of energy crops as well as costsupply relationships. The second effort is to identify wildlife and ecosystem diversity associated with energy crop deployment. This involves the collection of field data on biodiversity of energy crops, alternative land uses, and whole landscapes. The third effort has been to develop a better grasp of energy crop sustainability and interaction of energy crops production with controversial issues such as wetlands use, forest harvesting, agrichemical movement, and valuation of environmental externalities. Because there is yet no cellulosic liquid luels industry, ORNL has found working partners in rescarch with utilities, agritusiness, and the forest products industry for lield investigations.

\section{Environmental Rescarch and Analysis Highlights}

Cost-supply relationships and land use change. ORNL is using its GIS and resource assessment capabilities, in collaboration with other groups, to predict where energy crops may be grown. The methodologies for analyzing energy crop cost-supply relationships were first developed by using an East Tennessec conversion facility that requires 4()$)$-dry $\mathrm{Mg} / \mathrm{d}$ of wood. Land projected to be brought into encrgy crop production varied as a function of amount needed, hauling expenses, yields, and income from other crops. Figure 2 illustrales the relationship between biomass price, amount of land (hiomass supply), and distance from the East Tennessec conversion lacility. The lower the region number, the eloser the land is to the facility. Net changes in percentage of cropland utilized, net change in fertilizer use, change in crosion rates, 


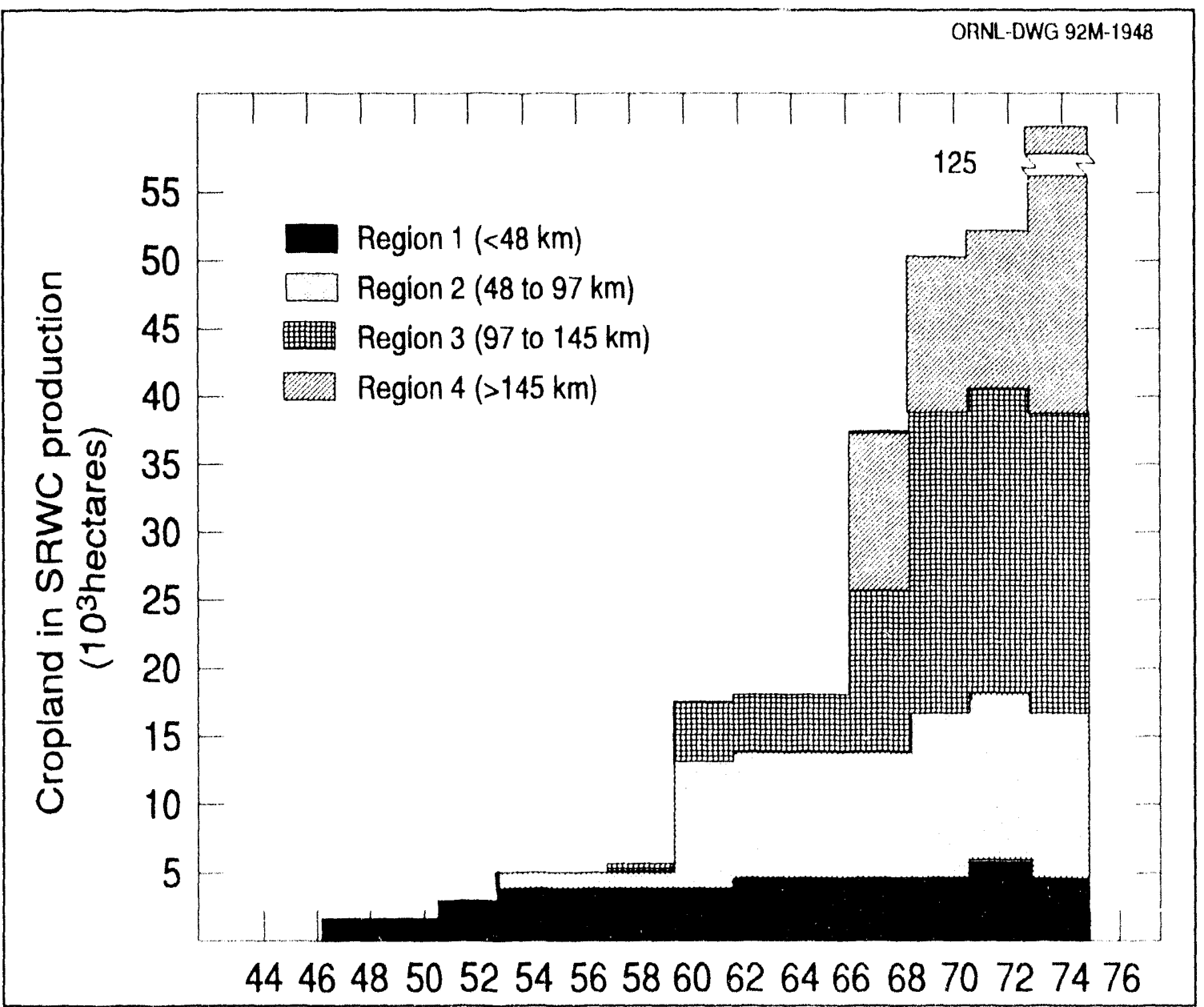

Fig. 2. Price of delivered SRWC wood (\$\$/dry Mg at Power Plant)

and farm income were calculated from this study. One important finding was that the most-productive croplands would be converted to woody crops before lessproductive croplands. The conversion of this type land, however, would result in reduced erosion and chemical use in the region closest to the power plant.

\section{Documentation of energy crop} biodiversity and landscape issues. An claborate interagency network was established to assess bird and small mammal diversity within short-rotation wood energy crops. Although efforts are concentrated at ten sites at seven locations simulating a regional transect (Fig. 3), additional sites in Canada and the Pacific
Northwest are under study to validate the Midwest lindings. Findings show that by the fourth or filth growing scason, bird diversity is greater in woody crop plantations than in pine plantations. rowerops, pastures, hayland, and native vegetation in carly successional stages. However, bird diversity is less in woody crop plantations than in mature woodland. Small mammal censuses yielded mixed results. Effects of woody crop plantations on landscape diversity appears to be most pronounced where 80 to $9(0 \%$ of the vegetation is in either agricuiture or forests. Where more equal mixes occur, woody crop plantings do not add or detract from the landscape patterns. 


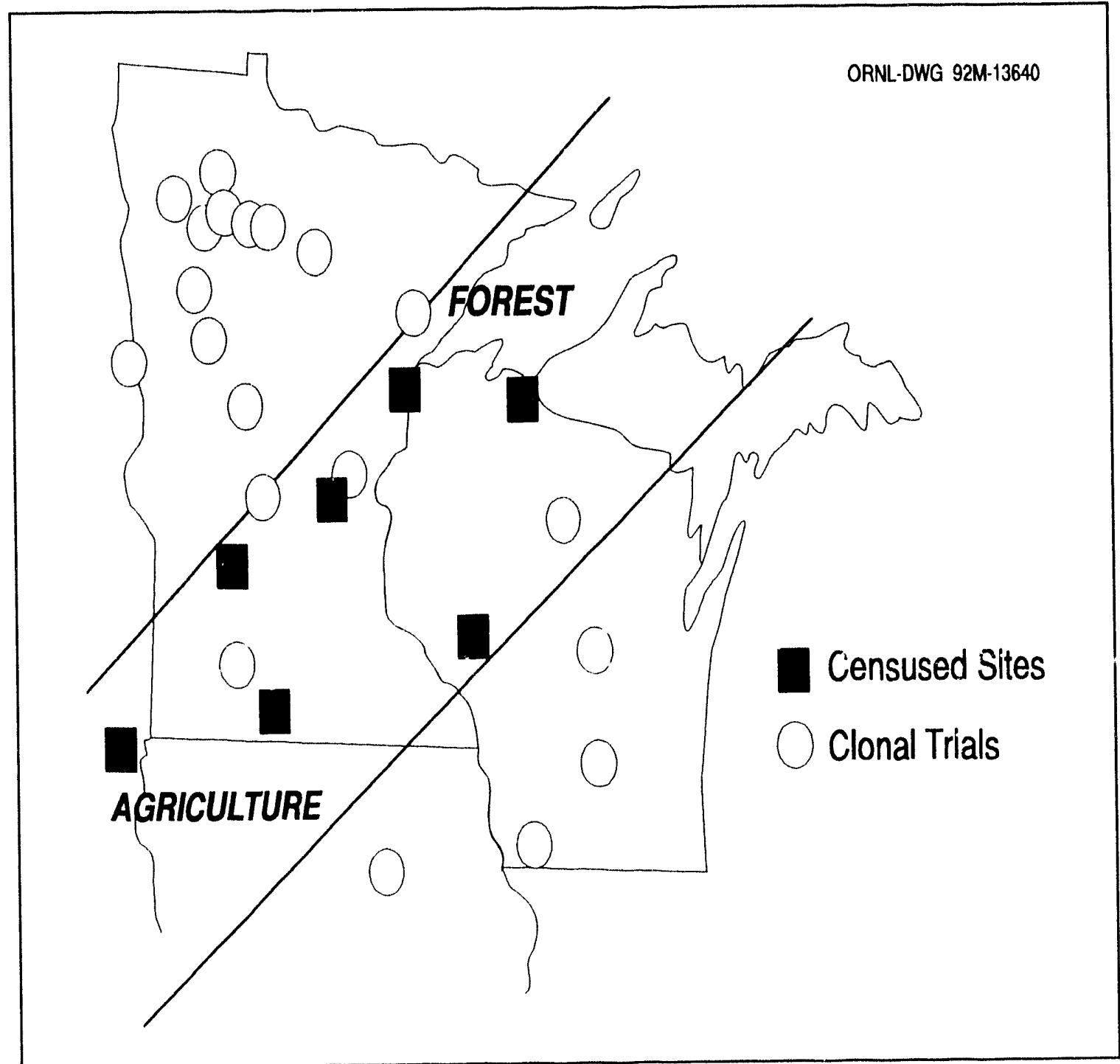

Fig. 3. Additional transect of species censusing in hybrid poplar plantations.

Additional work has been directed toward plant diversity beneath energy crops. The Michigan State Long Term Ecological Research Site (LTER), the only agricultural LTER, has provided important data toward this end. Results indicate that the understory vegeration in SRWC is statistically as diverse as old field succession and no-till corn for the first 3 years. Trends in diversity, especially of shade-tolerant species, suggest that understory diversity will continue to increase during the 6- to 10-year rotation of a SRWC stand.
Assessment of energy crop sustainability. Nutrient cycling occurs to a greater extent in most energy crops than in most agricultural crops. However sustained soil nutrient availability is not well documented in these crops because of the time and expense involved in experimentation. ORNL recently completed a study that evaluated the effect of fertilizer timing on nutrient cycle efficiency in an American sycamore plantation. This study indicated very high nitrogen retention rates (no groundwater pollution), except for the one-time-only 
treatment of $450 \mathrm{Kg} / \mathrm{hat}$ urea in the first year. The fertilization treatment that started at low rates and increased with tree size appeared to be most efficient. Spring and fall leaf phenology were unaffected by fertilization strategy. Of many possible nutrient stress indicators, nitrogen concentration in leaves appeared to be the most reliable, but better indicators are neceled. American sycamore did not increase nitrogen concentrations in wood but lended to recycle the nutrient externally through leat fall and rout capture to altain higher productivity.

\section{Other Environmental Issucs}

Because woody crops perform best on moist sites and appear capable of tolerating some amount of flooding, an interesting question arises about energy crop deployment might interact with the use of natural wetlands, farmed wetlands, and wet croplands. A dralt synthesis paper has been prepared that reviews wetland ypes, wedland definitions, wetland functions. caluses for wetlands destruction, and wetlands programs. The paper also discuss characteristics of energy crops with respect to habitats, chemical use, and land requirements and speculates on the effect energy crops would have on medilying the habitats of wet croplands. The report concludes that many wetland functions could be restored 10 "farmed and prior converted" wetlands by slightly modilied energy crop production techniques.

However, this would be problematic for landowners if their farmed or prior converted wetlands were to be reclassified and made subject to wetlands regulations. The relative value to socicty of potential energy crop benclits such as soil conservation, increased biodiversity, improved farm incomes, and reductions in nompoint agrichemical pollution such as fertilizer runoff deserves special attention.

\section{fiulure Plans}

Environmental assessment and rescarch are areas of the program in which major expansion in work eflort is needed and anticipated. As utilities anc eventually biofuel conversion lacilities begin to evaluate seriously the option of using cellulosic feedstocks, many questions will need to be immediately answered 10 lacilitate the permitting process. (ORNI is trying to anticipate these questions and 6 ) begin the rescarch and assessments that will be needed to answer the questions. Environmental assessments will be conducted under the newly formed "Integrated Systems" task. whereas environmental research requiring data collection will stand aldone as a sepatate lask.

As part of the Integrated Systems task, plans are under way to use environmental risk analysis methodologies developed al ORNI to assess biomatss energy systems risks. The considerable expertise available at ORNL on National Energy Policy Act (NEPA) regulations will be drawn upon to determine NIPA implications for cnergy crop production, handling and storage, and conversion ficility citing. It is our hope that a guideline for biomass energy systems feasibility assessments, which considers the full range of economic, environmental, and social effects can be prepared in the relatively near future.

Because the north central region and the Midwest are considered to be prime areas lor energy crop deployment, three more cost-supply curves are under development in Illinosis, Minnesota, and North Dakota. This will not only provide site-specilic information but will allow us to determine whether cost-supply palterns will differ greatly from location to location or enough similarities exist for making hroad generalizations in a region. Once the costsupply relationship are integrated with information from liceld investigations and 
models on biodiversity, agrichemical retention, and soil carbon, much better estimates of environmental risks and benelits can be made.

A regionwide study of energy crop supply has been initiated with the Tennessee Valley Authority for its electric service region. The study is evaluating the potential availability of wastes and residues as well as dedicated energy crops within reasonable haul distances of several facilities that may be candidates for burning biomass in combination with fossil lucks (co-firing). Preliminary tata indicate that relatively large quantities of energy crops could potentially be available at less than $\$ 50 /$ dry $\mathrm{Mg}$. Full results should be published within the next year.

The Environmental Research task will work 1) collect needed datit. Insulficient datla on lates of chemicals in energy crop systems and soil nutrient sustainability exists $t 0$ predict the long-term impacts of encrgy crop systems. An inceragency agreement with USDA's Tilth Laboratory in lowa will initiate preliminary effort loward understanding how chemicals applied to energy crops will move through hydrologic and ecological pathways. Identifying water quality effects of energy crops is a high priority. More comprehensive efforts are anticipated in FY 1993. To address soil nutrient sustainability questions, some modest effort is being directed loward the study of belowground diversity and dynamics (soil ecology). Soil ecology may be the best single integrated indicator of ecological function, sustainability, and biodiversity.

Even il the case can be made that hiomass energy systems that use dedicated energy crops produce overall benetits relative o fossil fuels systems and alternate land uses, there will still be considerable interest and concern about the environmental or ecological impacts of energy crop systems. For instance, concern exists about the increase in nuisance species that might inhabit energy crops. These types of questions cannot be answered until large plantings exist. As large plantings begin to be established by utilities or the biofuels industry, the Environmental Research task will plan studies to document results and assist in the development of hest management practices.

\section{ECONOMIC ANALYSIS AND INTEGRATION}

\section{Background and Strategy}

The Economic Analysis and Integration component seeks to ensure that all activities affecting the overall viability of biomass-based fuel cycles are understood and considered in program planning and research. This lask includes the translation of rescarch results into projections of estimated biomass production costs. Conversely, research in this task also indicates levels of production parameters that must be achieved to achieve the program cost goal.

Activities undertaken last year included starting on a project to develop energy crop supply curves for ethanol produced from corn; estimation of the energy inputs used in fertilizers and pesticides; and estimation of biomass transportation costs. Also, a synthesis study based on existing information for the Office of Technology Assessment of the U.S. Congress on biomass supplies, employment impacts, and environmental consequences; and estimation of supplies of biomass from existing forestry activities or lorest resources. The goals of these activities are to estimate biomass resource availability and resource requirements (c.g., land, energy, soil crosion). 


\section{Rescarch Highlights}

National supply and environmental modeling. One often asked question is how much hiomass can regionally be supplied"? To this question should be added at what price. A project under way in conjunction with The University of Tennessee is going to give us an answer (1) this question. On a regional basis, we are estimating what quantity of energy crops, and also corn, can be grown at what price. We are looking at corn because this is now the primary leedstock for ethanol production. In the luture, we expect encrgy crops to play a larger role than corn.

The basic scheme of the modeling system is presented in Fig. 4. The

Agricultural Resource Interregional Modelling System (ARIMS) is a lincar programming model of crop and livestock production in the United States. As a lincar program, ARIMS has the disadvantage of having lixed quantities of production regardless of the price. To deal with this shortcoming, we have linked ARIMS with an econometric model of U.S. agriculture known as POLYSIM. Inputs (o ARIMS are provided from the Erosion Productivity Impact Calculator (EPIC) and Budget Planner, a model that generates crop hudgets.

The purpose of this modeling system is to develop a tramework that will produce price-quantity data so that simple supply curves can be estimated for biomass feedstock production and impacts on soil erosion and chemical use can be estimated. By providing enough data points, we can econometrically estimate a supply curve that, once estimated, can be used without having to run the large modeling system. Supply curves will be estimated for energy crops and corn.

\section{$\mathrm{CO}_{2}$ and Biomass Production}

Papers were published in FY 1992 on $\mathrm{CO}_{2}$ emissions associated with corn-10ethanol production (Marland and Turhollow 1991) and from energy crop production (Turhollow and Perlack 1991). For corn to ethanol, about $25 \%$ of the $\mathrm{CO}_{2}$ emissions are from producing the corn grain and 75\% from fossil fuels used in the process of converting it from grain 10 ethanol. How the by-products from the process are treated is important in determining $\mathrm{CO}_{2}$ emissions allocated to the ethanol. In the base case, $\mathrm{CO}_{2}$ emissions (as C) for ethanol from corn are estimated at $16.45 \mathrm{~kg} / \mathrm{GJ}$. As a point of reference, gasolinc has $\mathrm{CO}_{2}$ emissions of $20.76 \mathrm{~kg} / \mathrm{GJ}$. The base casc assumes that coal is the source of energy for the conversion process, and the $\mathrm{CO}_{2}$ credit for the byproducts is based on displacement of soybean meal on a protein equivalent basis. Net $\mathrm{CO}_{2}$ emissions can be as low as 4.73 $\mathrm{kg} / \mathrm{GJ}$ of ethanol if hiomass is used as the fuel for the conversion process (Fig. 5).

Energy crops provide greater energy cutput per unit of energy input than corn and, hence, $\mathrm{CO}$, output is relatively lower. Estimates of (O), emissions were made for a SRWC (hybrid poplar), an annual grass (sorghum), and a perennial grass (switchgrass). Standing yiclds (i.c., yiclds betore accounting for all losses) are assumed to be 14, 1.5.8, and 13 dry $\mathrm{Mg} /$ ha for hybrid poplar, sorghum, and switchgrass, respectively, under current production technology. After accounting for losses, which are assumed to be 19, 16, and $31 \%, \mathrm{CO}$, cmissions were 1.30, 1.84 , and $1.93 \mathrm{~kg} / \mathrm{GiJ}$ for hybrid poplar, sorghum, and switchgrass, respectively, under current production technology. For future echnology, for which we assume higher yields, lower transportation energy 


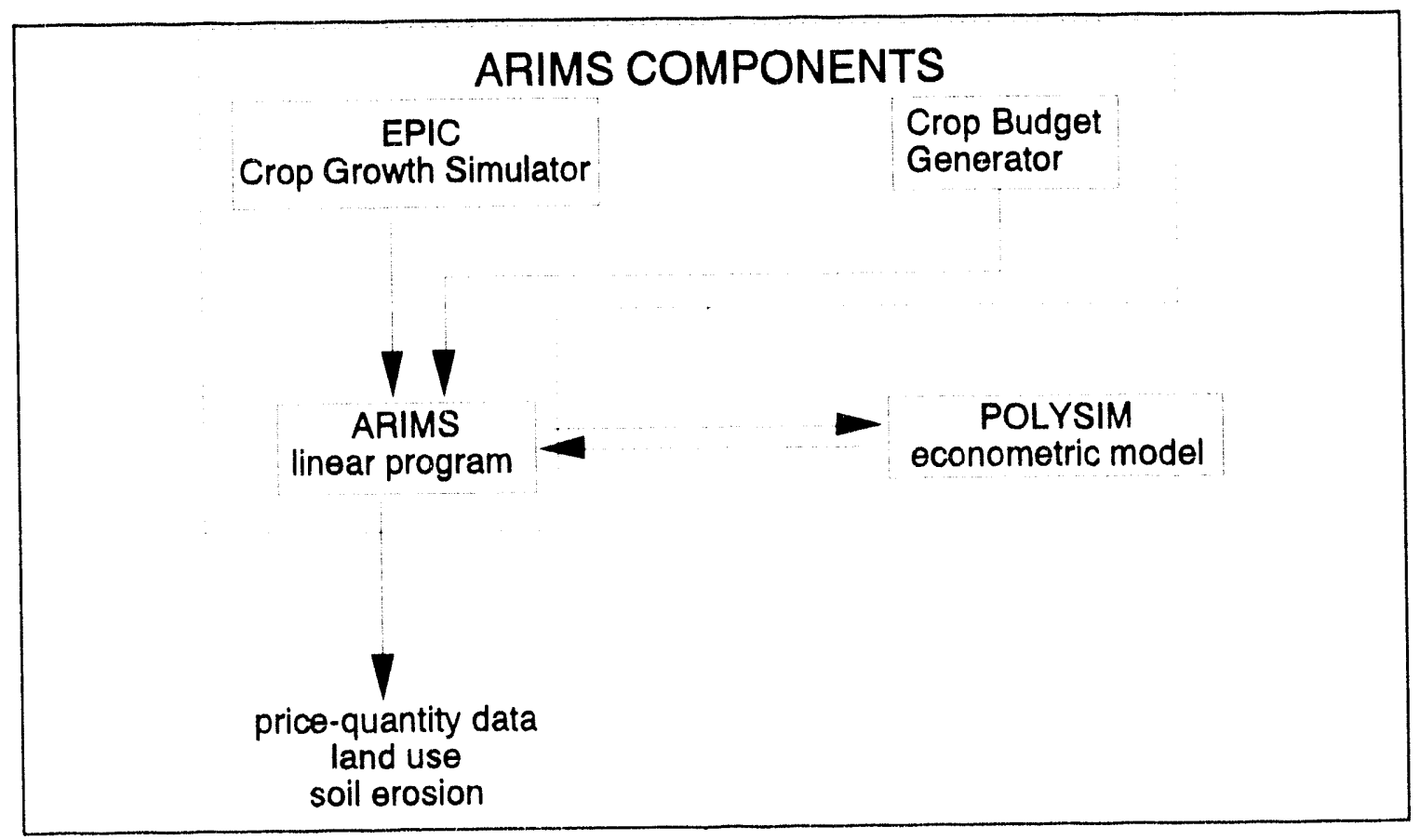

Fig. 4. Modeling system used to estimate national supply and environmental impacts.

requirements, and slightly lower energy losses, $\mathrm{CO}_{2}$ emissions are between 1.1 and $1.7 \mathrm{~kg} / \mathrm{GJ}$, significantly lower than that for fossil fuels (Fig. 6).

If the energy crops are used for electricity production. then Fig. 6 represents a fair comparison of energy crops to fossil luels (it the fuels have equal thermal conversion efficiencies to electricity). For liquid fuels, the biomass must be processed and thermal conversion efficiency is most likely to range from about $40 \%$ today to as high as $70 \%$ in the future. $\mathrm{CO}_{2}$ emissions from producing ethanol from energy crops with an assumed thermal conversion efficiency of $40^{\circ} \circ$ and no exogenous energy sources required are less than 25\% those of gasoline (Fig. 7). There may also be differences in luel efficiency between ethanol and gasoline that are not accounted for in Fig. 7.

\section{Future Plans}

The Economic Analysis and Integration task will hecome part of the Integrated Systems Task. During 1993 our estimation of baseline national supply, and environmental monitoring will be finished. From this, we will develop simple supply curves that can be widely used. The work with the Energy Information Administration and the Office of Technology Assessment of the U.S. Congress will be completed; from existing data we will have developed supply curves for conventional wood sources (e.g., whole tree chips, logging residues, mill residues). These are basically national-scale assessments, although there are regionalized supply curves. When commercialization occurs, it will be at a local scale. 


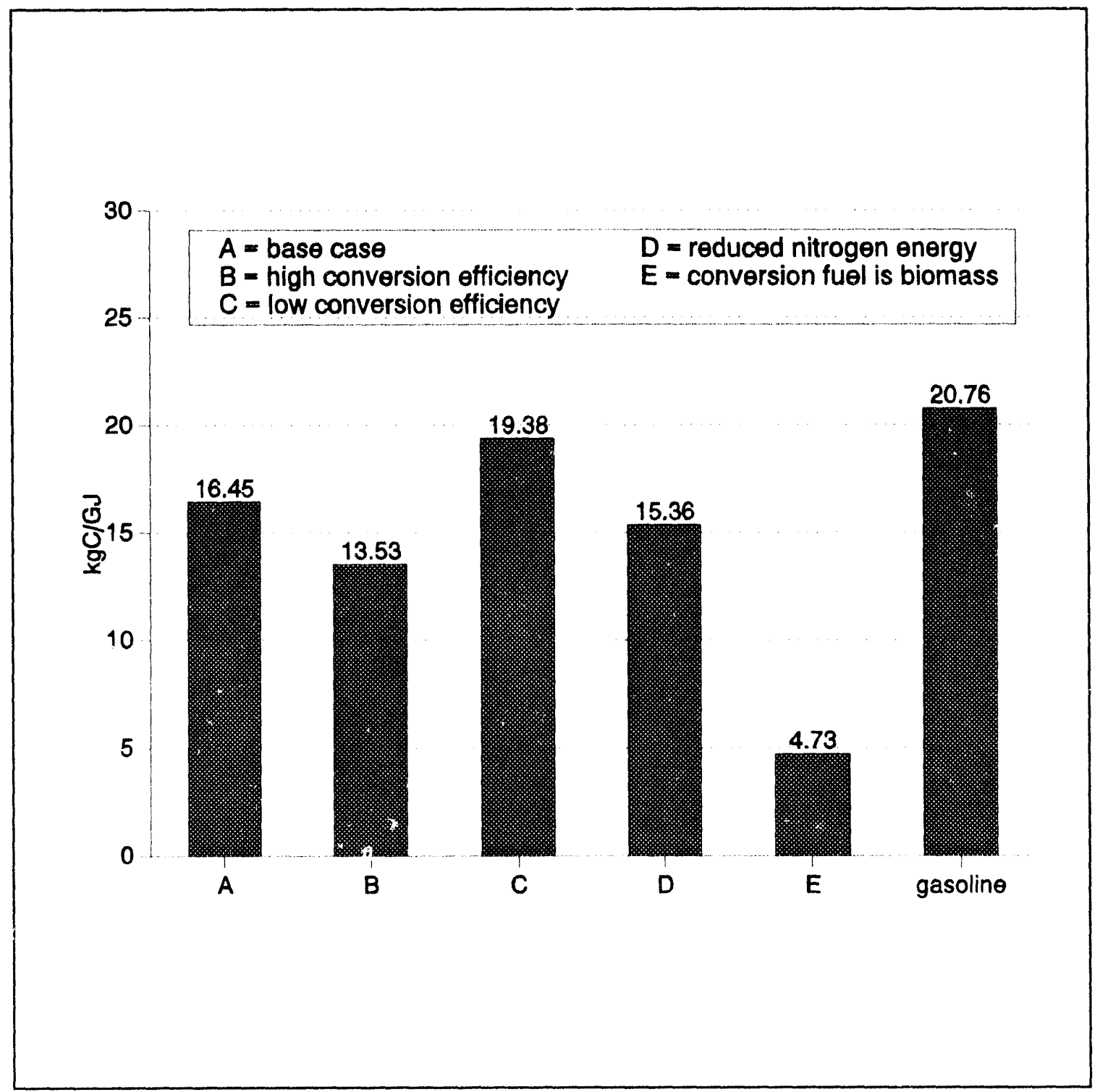

Fig. 5. $\mathrm{CO}_{2}$ emissions from ethanol produced from corn under varying assumptions.

Assessments must also be made at the local scale. We will undertake more sitespecific analyses that will focus on impacts on the local economy, such as the impact of a single or small number of conversion facilitics on a multicounty area. Among the impacts of interest are job creation and local husiness activity. 


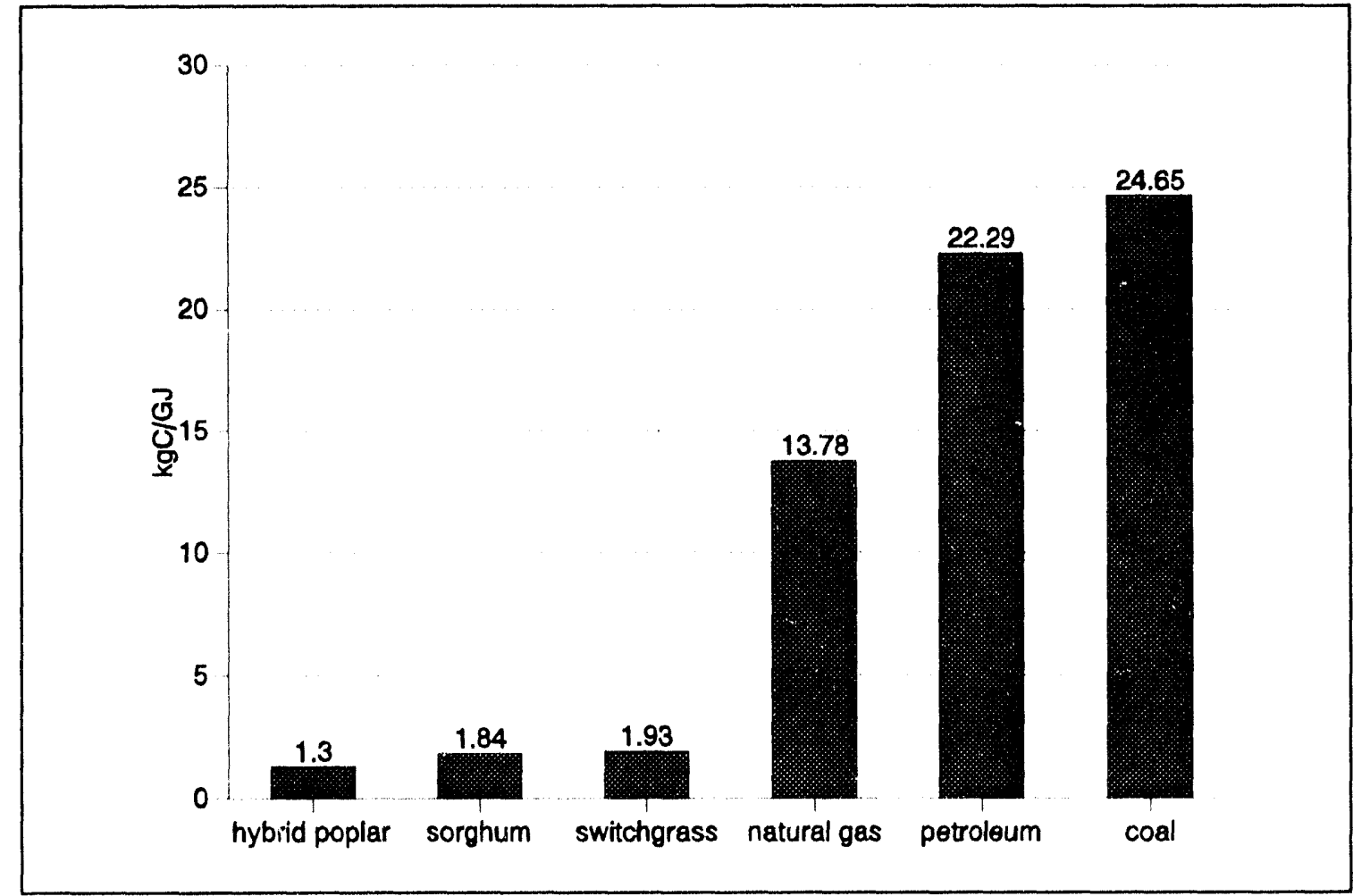

Fig. 6. Comparison of $\mathrm{CO}_{2}$ emissions from energy crops and fossil fuels.

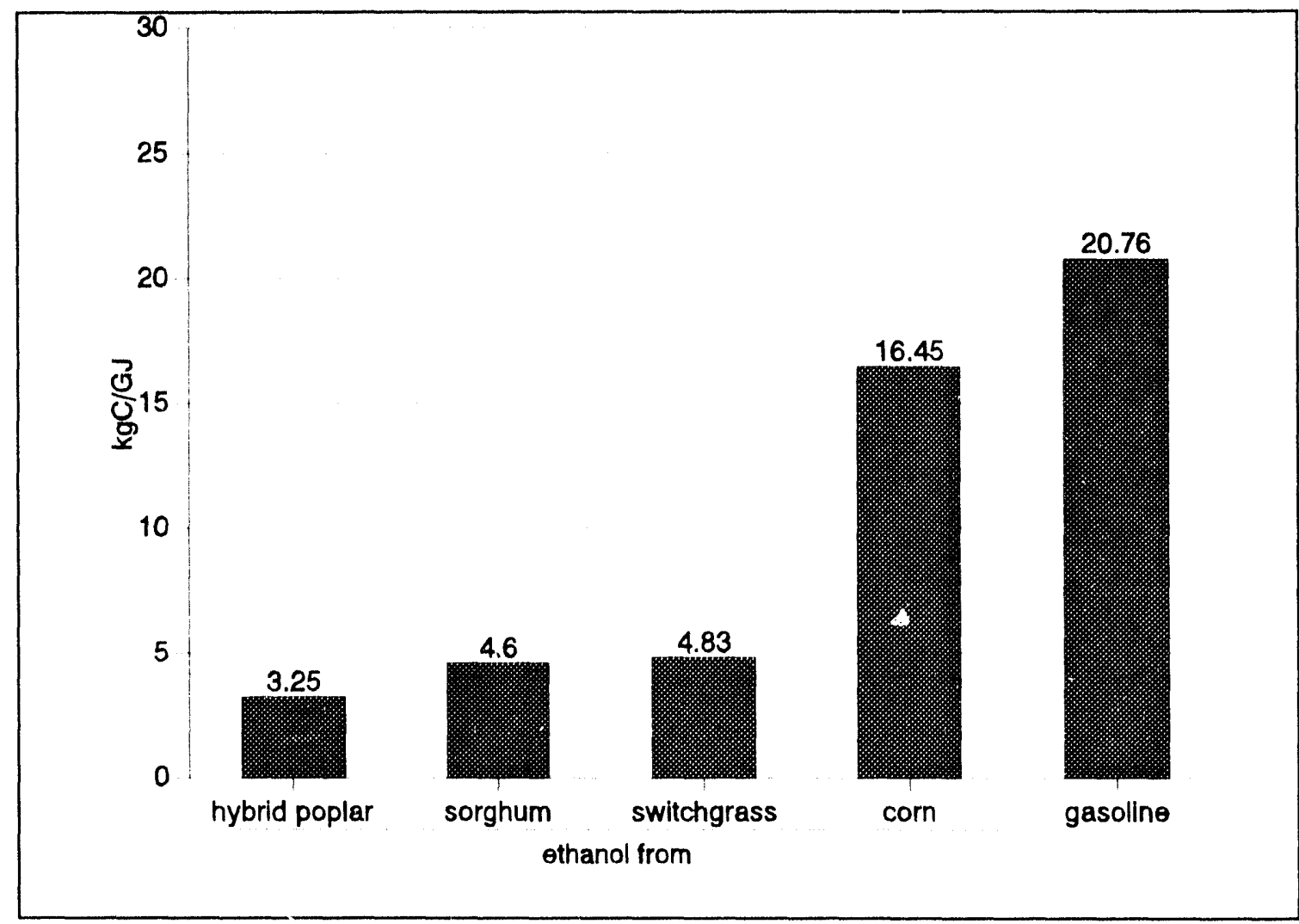

Fig. 7. Comparison of $\mathrm{CO}_{2}$ emissions from gasoline and ethanol produced from energy crops and corn. 


\section{ENERGY CROP DATA AND INFORMATION MANAGEMENT}

\section{INFORMATION MANAGEMENT ACTIVITIES}

During this reporting period, increased emphasis was placed on information management and dissemination activities as it became apparent that formal mechanisms would be needed to retrieve the massive amount of information available at ORNL as well as to respond to an ever-increasing number of information requests. To this end, several activities were undertaken or enhanced. Personal computer-based data bases were either created or expanded to serve as repositories and analysis tools for the data and materials supplied by principal investigators. Publication of Energy Crops

Forum, a newsletter, commenced. The extensive collection of multimedia resources was organized and catalogued, and the development of customized information packages was begun.

Since ORNL began acting as the technical manager for the DOE in 1978 for what is now the BFDP, more than 50) universities, USDA Forest Service laboratories, private individuals, and commercial organizations have funnelled information and research data to ORNL in fulfillment of contractual obligations as well as for use in regional and national assessments.

This information has been received in many different forms: numeric data reporting on research results, journal articles and reports, slides and photographs, unpublished papers and letters. In addition, the program stafl has amassed a voluminous collection of materials related to all aspects of production and use of energy crops to assist them in analyzing the results of the funded work.

In 1984, in response to the need to be able to simultaneously analyze numeric data from more than one research project at a time, the Short Rotation Woody Crops Data Base project was begun. The data base contains the location and type of field trials established with programmatic funding or co-funding, tracks actual and estimated growth and biomass yickd data and cultural practices, and transforms the information previously reported in various units and styles into units of information that can easily be compared and analyzed. This data base currently has almost 14 year's worth of information for more than 300 separate data elements for more than 25 projects.

A companion effort to computerize field data in a centrally available location was begun for herbaceous energy crops projects during this reporting period. This data hase will also contain the location and type of field trials, growth and biomass yicld data, and cultural practices will standardize the measurement units. Although the current data base design is being reviewed, data have been entered for seven completed projects with plans to incorporate data from two additional completed projects and new switchgrass research in the near future.

These two datasets, both alone and singly, are unique in their regional and national scope. As an example of the readily retrievable data, Table 1 provides an overview of recently reported biomass data for woody and herbaceous lield studies.

The principal investigators, under contract to the program and the stalf at 
Table 1. Recently reported energy crops yicld data

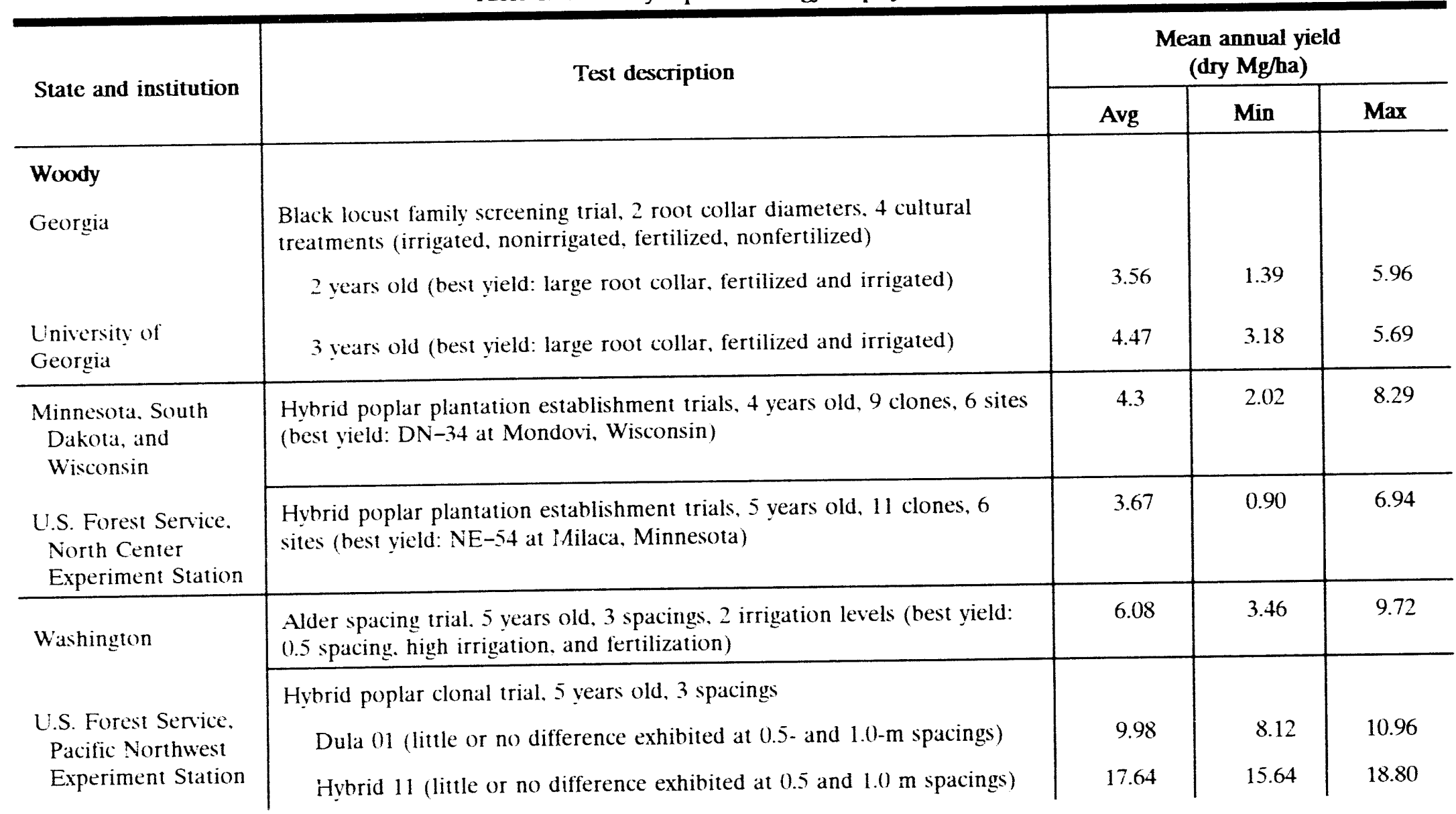


Table 1 (continued)

\begin{tabular}{|c|c|c|c|c|}
\hline \multirow{2}{*}{ State and institution } & \multirow{2}{*}{ Test description } & \multicolumn{3}{|c|}{$\begin{array}{l}\text { Mean annual yield } \\
\text { (dry Mg/ha) }\end{array}$} \\
\hline & & Avg & Min & $\operatorname{Max}$ \\
\hline Herbaceous & & & & \\
\hline Alabama & $\begin{array}{l}\text { Genotype/variety trial, } 4 \text { years old, } 8 \text { genotypes, } 12 \text { species (hest yield from } \\
\text { Alamo switchgrass) }\end{array}$ & 14.49 & 9.99 & 28.26 \\
\hline Auburn Liniversity & $\begin{array}{l}\text { Species screening trial. } 6 \text { years old. } 2 \text { species (best yield from hybrid energy } \\
\text { cane) }\end{array}$ & 17.27 & 6.10 & 25.60 \\
\hline $\begin{array}{l}\text { lowa } \\
\text { lowa State University }\end{array}$ & Species screening trial, 4 years old. 8 species (best yield from sweet sorghum) & 22.15 & 4.90 & 20.20 \\
\hline Kentucky & Species trial, 4 years old, 6 fertilizer levels (best yield from tall fescue) & & 4.31 & 10.28 \\
\hline Kentucky & Genotype test, 4 years old, 4 species (best yield from carthage switchgrass) & 17.19 & 12.50 & 22.00 \\
\hline $\begin{array}{l}\text { Indiana } \\
\text { Purdue University }\end{array}$ & $\begin{array}{l}\text { Species trial, } 3 \text { years old. } 8 \text { species. } 3 \text { fertilizer levels (best yield from } \\
\text { switchgrass) }\end{array}$ & 16.04 & 8.67 & 15.92 \\
\hline $\begin{array}{l}\text { New York } \\
\text { Cornell University }\end{array}$ & $\begin{array}{l}\text { Species screening trial. mixed root ages (mostly } 3 \text {-year old stand), } 9 \text { species } \\
\text { or mixtures. } 3 \text { fertilizer levels (best yield from flat pea) }\end{array}$ & 9.37 & 3.05 & 13.14 \\
\hline $\begin{array}{l}\text { North Dakota } \\
\text { North Dakota State } \\
\text { University }\end{array}$ & $\begin{array}{l}\text { Species screening trial, mixed root ages. } 13 \text { species or mixtures (best yield } \\
\text { from forage sorghum) }\end{array}$ & 16.73 & 2.10 & 18.30 \\
\hline $\begin{array}{l}\text { Ohio } \\
\text { Geophyta }\end{array}$ & $\begin{array}{l}\text { Species screening trial, } 5 \text { years old, } 8 \text { species or mixtures, (best yield from } \\
\text { mixture of rye and sorghum } x \text { sudangrass) }\end{array}$ & 14.11 & 4.10 & 23.10 \\
\hline $\begin{array}{l}\text { Virginia } \\
\text { Virginia Polytechnic } \\
\text { Institute and State } \\
\text { University }\end{array}$ & $\begin{array}{l}\text { Fertilization level trial, } 5 \text { years old. } 7 \text { fertilizer levels, (best yield from } \\
\text { switchgrass) }\end{array}$ & 9.28 & 4.40 & 12.00 \\
\hline
\end{tabular}


ORNL, have been extremely prolific writers, resulting in more than 2000 reports, journal articles, papers, theses, and dissertations. In 1988. a bibliographic data base was created to index these malerials for two reasons to ensure accessibility and to document program activities. Additional books. reports, conference procecedings, and reprints have also been collected to support in housc analyses and assessments. During this reperting period, a graduate student in library science from The University of Tennessec designed a subject catcegry shelving system for this exceptional collection of matcrials, as well as creating another bibliographic data base. Recently, the two data bases were combined, resulting in a file with more than 3500 kevworded entries that will be the cornerstone for an all-inclusive update (1) a bibliography originally published in $198 \%$.

Because ORNL is recognized as the premier authority on lecelsteck production issues, there are frequent requests for information. Not only is the bibliographic data base searched on an almose daily basis (1) identily and retrieve relevant materials, as is the 2700 record data base of slides and photographs that illustrate programmatic achicvements. Work has just been initiated on the creation of subjectspecific information packages composed of relevant reprints and reports, which will lacilitate quick response to the numerous information requests.

In the carly part of 1991, a decision was made to begin publishing a newsletter. The objectives were $t 0$ (1) facilitate communication and an awareness of ongoing research among the research community, (2) transfer rescarch results 10 those outside the rescarch community, and (3) identily and develop a constituency for energy crops rescarch. Initial eflorts consisted of the identification of members of the target audienee, which was defined as an international community of rescarchers in academia, gevernment organizations and private industry, policy and clecisionmakers at all levels of gevernment, privale citizens, public interest groups, and media contacts. The first issue of Energe Crops Fonum, published in the fall of 1992, was sent to approximately 1200 people. The reaction to the newsletler exceeded all expectations, with almost $75 \%$ of the original recipients indicating a desire to continue receiving it as well as yiclding more than 30() additiona! subscriber names. Referrals by current recipients and citations in other publications resulted in additional subscribers. The distribution list is hovering just bencath the 20000 level, and new subscription requests are being received almost daily. 


\section{FUTURE DIRECTIONS}

Research, development, and demonstration of dedicated feedstock supply systems is needed at a much broader scale than is currently planned by ORNL's BFDP. For the past 14 years, BFDP has been developing a technology for a future in which large amounts of biofuels are desired for energy selfsulficiency, global carbon mitigation, and rural economic enhancement. That future is approaching rapidly. There is a need to apply the knowledge already gained to demonstrate that our vision of significant contribution of biofuels to the U.S. economy can be a reality. This demands that a near-term integration and demonstration effort be added to ongoing long-term research and development activities.

The near-term research needs can best be understood by considering the efforts needed to facilitate commercial success at a single-facility level. The question currently being asked by both federal funding agencies and private sector investors is "what locations offer the greatest opportunity for suceess with the current technology"?" Integrated systems assessments could answer this question. Such assessments are required so that the complex interactions between and among energy markets, energy crops and cropping systems, the environment, economics. supply logistics, National Environmental Policy Act requirements, agricultural programs, and energy policies can be defined and evaluated. The newly planned Integrated Systems task within BFDP will include such activities as GIS analysis; complete fuel cycle analysis; economic, environmental, and sociological impact studies; landscape modeling; national and regional cost-supply modeling; tax effect studies; $\mathrm{CO}_{2}$ assessments; and nonmarket benefit valuations. Some of these activities will be conducted by cooperating in feasibility studies for specilic studies, whereas others will be more generic. The combined knowledge provided by these assessments will provide the ORNL staff with a holistic understanding of hiomass energy systems that can be used to guide the development of commercial projects both in the United States and internationally.

Assuming that one or more specific sites are selected for federally funded scale-ups or demonstrations of integrated biomass energy systems that use dedicated biomass leedstocks. energy crop technologies previously developed the the general region will need to be adapted to the specifie site. It will be important to synthesize energy crop information already available for the general region into "how(1)" guides specifically designed to assist farmers and industry in making decisions on which and what levels of energy crops (1) produce. Demonstration plantings should be established, and extension efforts should be initiated through traditional farmer's networks and information resources. Organization of field days to demonstrate planting and management techniques will be important. The best available tree seedling and/or herbaceous crop seed mixtures will need to be made available to local nurseries or seed producers to begin the process of multiplying the best available materials. Demonstrations will have the greatest likelihood for success if expertise on energy crop production (developed sy previous BFDP-funded research) is already available in the region. Although it may be reasonable for ORNL staff to be 
involved in the development of one or two specific projects, the role of ORNL stafl is anticipated normally to be that of advisors and providers of general information 10 local project developers. The ability of BFDP 10 fund site-specific demonstration activities will be severely limited at current budget levels. BFDP will be secking ways 16 participate in such demonstrations, however, so that environmental data can be collected and used for environmental impact analysis and for designing more covironmentally sound biomass energy systems.

To maintain a program with a national and long-term focus, technology development strategy is needed that is diverse and broad in its approach. A critical element is developing additional energy crops and cropping systems for several regions of the country. The crops and conpring technology available today simply will not supply the amounts of hionuass desired at the costs desired on the mallonal scale. New crops will be needed 11) suit different soil types, 6 reduce risks. 10 optimize environmental benetits, 10 more effectively utilize farm labor, and o provide lecedstocks in areas with serious climate and or soil limitation. Along with the development and genetic improvement of new crops, rescatch an the ecology of the crops and cropping systems needs 10 be expanded to ensure the development and implementation of environmentally sound production techniques. Because the development of new crops and environmentally sound cropping systems is a long-term process, it cannot be delayed. This is a large effort that could and should be shared by both USDA and DOE and as many state, local, and private research organizations ats possible. BFDP's crop development task will focus on just a few (ropse so that the value of crop) development elforts can be more quickly demonstrated. Likewise, the environmental research task will limit its evaluations 10 (1) those locations and cropping systems with a high probability of relatively near-term commercial potential and/or (2) existing commercial plantings.

To the extent that reducing the risks, both biological and economic, of producing large acreages of energy crops will become more and more important as more acces are planted, basic biological research on energy crops will be necessary to support the emerging industry. Integrated brecding, biotechonology, and physiological rescarch on selected energy crops will provide both crop specific information and new methodologies and hools for addressing problems associated with pests. discases, droughts, and other climatic stresses. This is also a lange eflont that is expected to need and utilize the resources (o) many different research groups.

()RNI S BFIPP anticipates supporting this type of elfurt only in conjunction with (rop) improsement rescarch.

The development of biomass encergy on a large scale both demands and justilies the development of spectalized harvesting and handling cyuipment. Reduction of harvest and handling system costs will be critically important io making the prices of dedicaled leedstocks competitive with other sources of encergy. It will be necessary for the rescarch community to define the equipment specilication, 61 conduct sufficient engine analysis to atearly detine the systems conditions under which the equipment should be expected to operate, and 10 identily the potential market. Private industry, however, is expected to play a large role in actual equipment production and tesling.

Both near-term and long-term research and implementation activities can be enhanced by ensuring that information already available is put in the hands of the people who need it. ORNL has a tremendous resource of materials on energy crop technology produced through 
research contracts and gathered by program staff over the past 14 years. This material needs to be made more aceessible to polential users through efficient information management and value-added information synthesis products. BFDP has hegun serious efforts to effectively manage biomass energy systems information and 10 generate useful information products. Copperattive efforts with NREL are being initialed so that the information can be presented with a complete hiomass energy systems focus.

ORNI has unique expertise in the biomass energy arenat as a result of the experiences acquired by its BFDP program managers. Four members of the stall have been with the program for more than 10 years, and most have heen associated with the program for more than 5 years. Consequently, most members of the BFDP stalf are in constant demand for giving presentations to local, state, national, and international groups; reviewing papers and proposals; participating in planning mectings and national roundtables; and giving advice to individuals and groups in the private sector. These activities are presumed to be valuable to DOE and will be continued to the extent possible.

However, such activities are not always compatible with efficient and eflective management of a diverse research program with projects located across the nation. ORNL will strive to seck an appropriate balance between technology transter and research management activities within the funding limits available. 
APPENDIX A

BIOFUELS FEEDSTOCK DEVELOPMENT PROGRAM PROJECTS 
Table A-1. Biofucls Fecdstock Development Program projects

\begin{tabular}{|c|c|c|}
\hline Institution & Investigator & Title \\
\hline Amana Socicty & $\begin{array}{l}\text { L. G. Gnewikow } \\
\text { D. Shoup }\end{array}$ & $\begin{array}{l}\text { Monoculture Viahility Trial of Woody } \\
\text { Crops for Encrgy Production }\end{array}$ \\
\hline Auhurn University & J. A. Mosjidis & $\begin{array}{l}\text { Variability for Biomass Production and } \\
\text { Plant Composition in Sericea Lespedeza } \\
\text { Germ Plasm }\end{array}$ \\
\hline \multirow[t]{2}{*}{ Auburn University } & D. I. Branshy & $\begin{array}{l}\text { Selection and Improvement of } \\
\text { Herbaceous Energy Crops for the } \\
\text { Southeastern USA }\end{array}$ \\
\hline & & $\begin{array}{l}\text { Biomass Energy Strategies for Carbon } \\
\text { Dioxide Mitigation in the United States }\end{array}$ \\
\hline Auhurn University & D. I. Branshy & $\begin{array}{l}\text { Development of Optimal Establishment } \\
\text { and Cultural Practices for Switchgrass }\end{array}$ \\
\hline Iowa State University & $\begin{array}{l}\text { R. B. Hall } \\
\text { E. R. Hart } \\
\text { H. S. McNabh, Jr. } \\
\text { R. C. Schultz. }\end{array}$ & $\begin{array}{l}\text { Selection and Breeding of Pest-Resistant } \\
\text { Clones of Populus for Biomass Energy } \\
\text { Production in the North Central Region }\end{array}$ \\
\hline lowa State University & $\begin{array}{l}\text { I. C. Anderson } \\
\text { D. R. Buxion } \\
\text { C. S. Accola }\end{array}$ & $\begin{array}{l}\text { Selection of Herbaceous Energy Crops } \\
\text { for Production in Double Cropping } \\
\text { Systems }\end{array}$ \\
\hline Michigan State University & $\begin{array}{l}\text { D. I. Dickmann } \\
\text { K. S. Pregitzer }\end{array}$ & $\begin{array}{l}\text { Net Assimilation and Photosynthate } \\
\text { Allocation of SRIC Populus Clones }\end{array}$ \\
\hline $\begin{array}{l}\text { Mississippi Agricultural \& } \\
\text { Forestry Experiment } \\
\text { Station }\end{array}$ & S. B. Land & $\begin{array}{l}\text { Early Selection Criteria and Clonal } \\
\text { Propagation Methods for Increased } \\
\text { Productivity of Sycamore in Short- } \\
\text { Rotation Energy Systems }\end{array}$ \\
\hline $\begin{array}{l}\text { North Dakota State } \\
\text { University }\end{array}$ & $\begin{array}{l}\text { D. W. Meyer } \\
\text { D. O. Erickson } \\
\text { R. G. Johnson }\end{array}$ & $\begin{array}{l}\text { Evaluation of Herbaceous Biomass } \\
\text { Crops in the Northern Greal Plains }\end{array}$ \\
\hline $\begin{array}{l}\text { Oak Ridge National } \\
\text { Laboratory }\end{array}$ & $\begin{array}{l}\text { H. Van Miegrocl } \\
\text { R. J. Norby }\end{array}$ & $\begin{array}{l}\text { Optimum Nitrogen Nutrition in Short- } \\
\text { Rotation Sycamore Plantations }\end{array}$ \\
\hline $\begin{array}{l}\text { Oak Ridge National } \\
\text { Laboratory }\end{array}$ & .. W. Ranncy & Environmental Planning and Analysis \\
\hline $\begin{array}{l}\text { Oak Ridge National } \\
\text { Laboratory }\end{array}$ & S. D. Wullschleger & $\begin{array}{l}\text { Switchgrass Physiological Development } \\
\text { for the Southeast }\end{array}$ \\
\hline
\end{tabular}


Table A-1 (continued)

\begin{tabular}{|c|c|c|}
\hline Institution & Investigator & Title \\
\hline $\begin{array}{l}\text { Oak Ridge National } \\
\text { Lathiatory }\end{array}$ & $\begin{array}{l}\text { G. A. Tuskan } \\
\text { T. J. Tschaplinski }\end{array}$ & $\begin{array}{l}\text { Improvement of Energy Crop Responses } \\
\text { to Drought Stress }\end{array}$ \\
\hline Oklahoma State University & C. G. Tauer & $\begin{array}{l}\text { Preserving Populus Germ Plasm for } \\
\text { Breeding Programs }\end{array}$ \\
\hline Oklahoma State University & C. M. Taliaferro & $\begin{array}{l}\text { Breeding and Selection of New } \\
\text { Switchgrass Varictics for Increased } \\
\text { Biomass Production }\end{array}$ \\
\hline Purdue University & K. D. Johnson & $\begin{array}{l}\text { Evaluation of Potential Herbaceous } \\
\text { Biomass Crops on Marginal Land }\end{array}$ \\
\hline Southern Illinois University & $\begin{array}{l}\text { W. C. Ashby } \\
\text { J. E. Precec } \\
\text { P. L. Roth }\end{array}$ & $\begin{array}{l}\text { Genetic Biomass and Growth Analysis } \\
\text { of Clonal Silver Maple (Acer } \\
\text { saccharimum L.) in Several Locations }\end{array}$ \\
\hline $\begin{array}{l}\text { State University of New } \\
\text { York }\end{array}$ & E. H. Whitc & Bioenergy from Willow \\
\hline Texas AdkM University & M. A. Sanderson & $\begin{array}{l}\text { Evaluation of Switchgrass Cultivars and } \\
\text { Cultural Methods in the South Central } \\
\text { U.S. }\end{array}$ \\
\hline Tuskegee University & A. Weaver & Biomass Research and Training Program \\
\hline University of Georgia & $\begin{array}{l}\text { B. C. Bongarten } \\
\text { S. Merkle } \\
\text { M. Crump }\end{array}$ & $\begin{array}{l}\text { Optimizing Energy Yields in Black } \\
\text { Locust Through Cienetic Selection }\end{array}$ \\
\hline University of Georgia & P. L. Raymer & U.S. 1992 Rapeseed Varicty Trials \\
\hline University of Idaho & K. A. Mahler & $\begin{array}{l}\text { Development of Broadly Adapted } \\
\text { Cultivars of Winter Rapeseed as a } \\
\text { Source of Diesel Fuel }\end{array}$ \\
\hline University of Kentucky & M. Collins & $\begin{array}{l}\text { Biomass Production by Fescue and } \\
\text { Switchgrass Alone and in Mixed Swards } \\
\text { with Legumes }\end{array}$ \\
\hline The University of Tennessec & B. C. English & $\begin{array}{l}\text { Subregional Cost Supply Studies and } \\
\text { Economic and Technical Analyses }\end{array}$ \\
\hline The University of Tennessee & $\begin{array}{l}\text { B. C. English } \\
\text { M. G. Bhat }\end{array}$ & Synthesis of Energy Crop Potential \\
\hline The University of Tennessee & B. C. English & Economic and Technical Analyses \\
\hline
\end{tabular}


Table A-1 (continued)

\begin{tabular}{|c|c|c|}
\hline Institution & Investigator & Tille \\
\hline The University of Tennessee & S. E. Schlarbaum & $\begin{array}{l}\text { Black Locust Provenance Data } \\
\text { Collection and Analysis }\end{array}$ \\
\hline University of Washington & $\begin{array}{l}\text { R. F. Stetller } \\
\text { P. E. Heilman } \\
\text { T. M. Hinckley } \\
\text { H. D. Bradshaw, Jr. }\end{array}$ & $\begin{array}{l}\text { Genctic Improvement and Evaluation of } \\
\text { Black Cottonwood for Short-Rotation } \\
\text { Biomass Production }\end{array}$ \\
\hline $\begin{array}{l}\text { USDA Agricultural } \\
\text { Research Service }\end{array}$ & K. P. Vogel & Genetic Variation Among Switchgrasses \\
\hline $\begin{array}{l}\text { USDA Forest Service North } \\
\text { Central Forest Experiment } \\
\text { Station }\end{array}$ & $\begin{array}{l}\text { J. G. Isebrands } \\
\text { B. E. Haissig }\end{array}$ & $\begin{array}{l}\text { Increasing Yiclds of Poplar Energy } \\
\text { Plantations }\end{array}$ \\
\hline $\begin{array}{l}\text { USDA Forest Service North } \\
\text { Central Forest Experiment } \\
\text { Station }\end{array}$ & $\begin{array}{l}\text { E. A. Hansen } \\
\text { D. Netzer }\end{array}$ & $\begin{array}{l}\text { Short-Rotation Woody Crop Trials for } \\
\text { Energy Production in the North Central } \\
\text { United States }\end{array}$ \\
\hline $\begin{array}{l}\text { USDA Forest Service } \\
\text { Pacific Northwest } \\
\text { Research Station }\end{array}$ & $\begin{array}{l}\text { D. S. DeBell } \\
\text { C. A. Harrington } \\
\text { G. W. Clendenen }\end{array}$ & $\begin{array}{l}\text { Increasing the Productivity of Biomass } \\
\text { Plantations of Alder and Cottonwood in } \\
\text { the Pacific Northwest }\end{array}$ \\
\hline $\begin{array}{l}\text { Virginia Polytechnic } \\
\text { Institute and State } \\
\text { University }\end{array}$ & $\begin{array}{l}\text { D. J. Parrish } \\
\text { D. D. Wolf } \\
\text { W. L. Danicls }\end{array}$ & $\begin{array}{l}\text { Switchgrass as a Biofucls Crop for the } \\
\text { Upper Southeast }\end{array}$ \\
\hline
\end{tabular}

"Other institutions cost sharing the Amana Society contract include Iowa State Iniversity, the lowa Department of Natural Resources (I)NR) Fenergy and (ieological Resources Division, and the lowa DNR forestry Division. 
ORNL-6781

\section{INTERNAL DISTRIBUTION}

1. L. D. Bates

2. R. S. Carlsmith

3. T. R. Curlee

4-23. J. H. Cushman

24-43. A. R. Ehrenshaft

44. M. P. Farrell

45. D. E. Fowler

46. W. Fulkerson

47. C. W. Gehrs

48. R. L. Graham

49. S. G. Hildebrand

50. P. Kanciruk

51. S. B. McLaughlin $52-71$

72.
W. A. McNabb

R. J. Norby
73. R. D. Perlack

74-93. J. W. Ranney

94. D. E. Reichle

95. F. E. Sharples

96. D. S. Shriner

97. S. H. Stow

98. T. Tschaplinski

99. G. A. Tuskan

10(0-119. L. L. Wright

120. S. D. Wullschleger

121. Central Rescarch Library

122-136. ESD Library

137-138. Laboratory Records Dept.

139. Laboratory Records, RC

140. ORNL Patent Office

141. ORNL Y-12 Technical Library

\section{EXTERNAL DISTRIBUTION}

142. C. S. Accola, Iowa State University, 1496 Agronomy Hall, Ames, IA 50011

143. J. Allsup, Office of Alternative Fuels, U.S. Department of Energy, Forrestal Bldg., 1000 Independence Ave., S.W., Washington, DC 20585

144. I. C. Anderson, Iowa State University, Dept. of Agronomy, Ames, IA 50(011

145. P. C. Badger, Southeastern Regional Biomass Energy Program, National Fertilizer Development Center, Tennessee Valley Authority, Muscle Shoals, AL 35660)

146. J. Berning, Electric Power Research Institute, 3412 Hillview Avenue, Palo Alto, CA 94303

147. D. Betters, Colorado State University, Forest \& Wood Sciences, Room 129 , Forestry Bldg., Fort Collins, CO 80523

148. M. Bhat, University of Tennessec, P.O. Box 1071, Knoxville, TN 37901

149. D. Binkley, Colorado State University, Forestry Department, Ft. Collins, CO 80523

150). J. Birk, Electric Power Rescarch Institute, 3412 Hillvicw Avenue, P.O. Box 10412, Palo Alto, CA 94303

151. P. R. Blankenhorn, Pennsylvania State University, School of Forest Resourees, 310 Forest Rescarch Lab., University Park, PA $168(12$

152. A. A. Boe, South Dakota State University, Dept. of Plant Science, Brooking, SD $57(0) 7$

153. B. Bongarten, University of Georgia, School of Forest Resources, Athens, GA 30602 
154. D. Boron, Department of Energy, 1000 Independence Avenue S.W., Forrestal Building, CE-2.32, 5F-059, Washington, DC 20585

155. T. Bradshaw, University of Washington, Dept. of Biochemistry SJ-70, Seattle, WA 98195

156. D. I. Bransby, Auburn University, Dept. of Agronomy \& Soils, 202 Funchess Hall, Auburn, AL 36849-4109

157. D. R. Buxton, USDA-ARS, National Program Staff, BARC-West, Building (0)5, Rm 232, Beltsville, MD 20705

158. I. T. Carlson, Iowa State University, Department of Agronomy, Ames, IA 50011-1010)

159. J. Carpenter, SEEC, 21 E. Market Street, P.O. Box 466, Marictta, PA 17547

160. H. Chum, National Renewable Energy Laboratory, 1617 Cole Blvd., Golden, CO 8()401-3393

161. D. P. Christian, University of Minnesota, Department of Biology, 10 University Drive, Duluth, MN 55812

162. X. Clay, Indiana University, Department of Biology, 1575 Linden Drive, Bloomington, IN 47405

163. M. Collins, University of Kentucky, Dept. of Agronomy, N-122 Ag. Sci. Bldg. North, Lexington, KY 40546-()(091

164. B. Conger, University of Tennessee, Dept. of Plant and Soil Science, Knoxville, TN 37901-1071

165. R. Conway, U.S. Department of Agriculture, Office of Energy, OE, RM 144E, Admin. Bldg., Washington, DC 20250

166. J. H. Cook, National Audubon Society, Scully Science Center, 550 South Bay Avenuc, Islip, NY 11751

167. R. Costello, U.S. Dept. of Energy, Biofuels Systems Division, Forrestal Bldg., CD-331, 100() Independence Ave, SW, Washington, DC 20585

168. J. S. Cundift, Virginia Tech, Dept of Agricultural Enginecring, Blacksburg, VA $24061-(030) 3$

169. W. L. Danicls, Virginia Tech, Dept. of Agronomy, Blacksburg, VA 24061

170. M. Davison, Champion International, 37 Villa Road, Suite 319-B141, Greenville, SC 29615

171. David H. Dawson, 3015 S. River Road, P.O. Box 1321, Rhinelander, WI 545() 1

172. D. S. DeBell, USDA Forest Service, Forestry Sciences Laboratory, 3625 9. rd Avenuc, S.W., Olympia, WA 985012

1\%3. J. Demetrops, Director, State Energy Programs, U.S. Department of Energy, 100() Independence Ave., S.W., CE-522, Washington, DC 20585

174. D. I. Dickmann, Department of Forestry, Michigan State University, East Lansing, MI 48824-1222

175. B. English, University of Tennessec, Dept. Agric. Economics \& Rural Sociology, P. O. Box 1071, Knoxville, TN 37901-1071

176. R. N. Farvolden, Professor, Department of Earth Sciences, University of Waterloo, Waterloo, Ontario N2L 3G1 Canada

177-178. J. E. Ferrell, Bioluels Systems Division, CE 331, U.S. Department of Energy, Washington, DC 20545

179. P. Fox, Bonneville Power Administration, P.O. Box 3621, Routing EPG, Portland, OR 97208 
180. B. Gambles, University of Toronto, Faculty of Forestry, 33 Willeocks St., Toronto, M5S 3B3, Canada

181. E. E. Gavett, 2608 Bowling Green Drive, Vienna, VA 22180

182. S. Gronich, U.S. Department of Energy, CE-132, 5H-1)59, Forrestal Building, 1000 Independence Ave. S.W., Washingion, LC 20585

183. T. Gross, U.S Department of Fnergy, Otrice of Transportation Technologies. 1000) Independence Ave. S.W., Washington, DC 20585

184. B. Haissig, USDA Forest Service, Forestry Science Laboratory, P.O. Box 98, Rhinclander, WI 54501

185. R. B. Hall, Forestry Department, 251 Bessey Hall, Iowa State University, Ames, IA 50)11

186. Richard Handley, Coalition of Northeastern Governors, 400) North Capitol Strect N.W., Suite 382 , Washington, DC 20001

187. E. A. Hansen, USDA Forest Service, Forestry Sciences Laboratory, 1831 Highway 169 East, Grand Rapids, MN 55744

188. J. M. Hanowski, University of Minnesota, NRRI, 5013 Miller Trunk Highway, Duluth, MN 55811

189. L. Harris, USDA, U.S. Forest Service, Agricultural Research Service, BARCW, Bldg. 0(15, Room 236, Beltsville, MD 20705

190. R. C. Harriss, Institute for the Study of Earth, Oceans, and Space, Science and Engineering Research Building, University of New Hampshire, Durham, NH 0.3824

191. W. Hart, Iowa State University, Dept. of Entomology, 403 Science II, Ames, IA $500111-3222$

192. J. Hattield, USDA/ARS, National Soil Tilth Lab., 2150 Pammel Drive, Ames IA 50011

193. P. E. Heilman, Western Washington Research and Extension Center, Puyallup, WA 98371

194. T. Hinckley, University of Washington, College of Forest Resources, Scattle, WA 98195

195. N. Hinman, National Renewable Energy Laboratory, 1617 Cole Blvd., Golden, $\mathrm{CO} 8(140) 1$

196. W. Hoffman, National Audubon Socicty, 115 Indian Mound Trail, Tavernier, FL . 33070

197. J. G. Ischrands, USDA Forest Service, Forestry Sciences Laboratory, P.O. Box 898, Rhinelander, WI 54501

198. W. Johnson, University of Minnesota, Dowell Hall, Crookston, MN 56716

199. G. Y. Jordy, Office of Program Analysis, Office of Energy Research, ER-30, G-226, U.S. Department of Energy, Washington, DC 20545

200. P. Kormanik, Institute of Tree Root Biology, Forest Sciences Lab., Carlton Street, Athens, GA $3060(2)$

201. F. J. Kuzel, Council of Great Lakes Governors, 310 S. Michigan Ave., 10th Floor, Chicago, IL 606(14

202. S. B. Land, Jr., Department of Forestry, P.O. Drawer FR, Mississippi State University, Mississippi State, MS 39762

203. H. L. Lane, U.S. Department of Energy, Office Conservation \& Renewable Encrgy, Office of State and Local Programs, Washington, DC 20585

204. P. A. Layton, Scott Paper Worldwide, Scolt Plaza III, Philadelphia, PA 19113 
205. S. McNabb, Iowa State University, Dept. of Forestry, 251 Bessey Hall, Ames, IA 50011

206. S. Merkle, University of Georgia, School of Forest Resources, Athens, GA 30602

207. D. W. Meyer, North Dakota State University, Crop and Weed Sciences Department, 166 Loftsgard Hall, SU Station, Fargo, ND 58105-5051

208. R. Moorer, Office of Transportation Technologies, U.S. Department of Energy, 1000 Independence Ave., S.W., Washington, DC 20585

209. W. Murphey, USDA-CSRS, Rm. 329 M Aerospace Center, 9()1 M Street, S.W., Washington, DC 20250-2200)

210. G. J. Niemi, University of Minnesota, Center for Water and the Environment, Natural Resources Research Institute, 5013 Miller Trunk Highway, Duluth, MN 55811

211. D. Netzer, USDA Forest Service, North Central Forest Exp. Station, Forestry Sciences Laboratory, P.O. Box 898, Rhinclander, WI 54501

212. R. P. Overend, National Renewable Energy Laboratory, Fuels \& Chemicals Research \& Engr. Div., 1617 Cole Blvd., Golden, CO $5(1401$ 1-3393

213. D. J. Parrish, Virginia Tech, Dept. of Agronomy, Blacksburg, VA 24061

214. A. Patrinos, Environmental Sciences Division, Office of Health and Environmental Rescarch, ER-74, U.S. Department of Energy, Washington, DC 20585

215. J. Peterson, New York State Energy Rescarch and Development Authority, Agency Bldg. \#2, Empire Statc Plaza, Albany, NY 12223

216. C. S. Prakash, Tuskegee University, School of Agriculture, Milhank Hall, Tuskegec, AL 36088

217. J. Preece, Department of Plant and Soil Science, Southern Illinois University, Carbondale, IL 62901

218. K. Pregitzer, Michigan State University, Dept. of Forestry, 111 Natural Resources Building, East Lansing, MI 48824-1222

219. R. A. Samson, REAP-Canada, Box 125 Glenaladale House, Ste-Anne-DeBellevue, Quebec, H9X $1 \mathrm{CO}$

220. M. A. Sanderson, The Texas A\&M University, Texas Agricultural Experiment Station, Route 2, Box (00), Stephenville, TX 76401

221. L. Schilling, U.S. Department of Energy, Improved Energy Productivity, 1000) Independence Ave. S.W., Washington, DC 20585

222. K. R. Schubert, University of Oklahoma, Dept. of Botany \& Microt iology, 770) Van Vleet Oval Rm. 135, Norman, OK 73019-(1245

223. S. Sladden, Auburn University, 202 Funchess Hall, Auburn, AL 36849

224. D. A. Sleper, University of Missouri, Dept. of Agronomy, 210 Waters Hall, Columbia, MO 65211

225. R. F. Stettler, College of Forest Resources, University of Washington, Seattle, WA 98195

226. C. H. Strauss, School of Forest Resources, Pennsylvania State University, University Park, PA $68(12$

227. S. Strobl, Ontario Ministry of Natural Resources, Fast Forests, P. O. Box 605, Brockville, ONT K6V 5 Y8

228. D. Swanson, Western Regional Biomass Energy Program, WAPA, P. O. Box 3402. Golden, CO 804()1 
229. C. M. Taliaferro, Oklahoma State University, Department of Agronomy, Stillwater, OK 74078

230. C. G. Tauer, Oklahoma State University, (012 S. Agriculture Hall, Stillwater, OK 74078

231. J. I1. Turnbull, Electric Power Research Institute, Storage and Rencwables Department, P. O. Box 10412, Palo Alto, CA 943013

232. Ken Vogel, University of Nebraska, USDA-ARS, 332 Keim Hall, Lincoln, NE 68583-(19)10

233. M. Voorhies, U.S. Department of Energy, Regional Biomass Program, CE-522 Forrestal Building, 10(0) Independence Ave. S.W., Washington, DC 20585

234. E. H. White, College of Environmental Science and Forestry, State University of New York, Syracuse Campus, Syracuse, NY 1.3210

235. F. J. Wobber, Environmental Sciences Division, Office of realth and Environmental Rescarch, ER-74, U.S. Department of Energy, Washington, DC: 20585

236. D. Wiley, Department of Energy, 1000) Independence Ave. S.W., Forrestal Building, CE-231, 5F-(1).59, Washington, DC 20.585

237. A. Wisclogel, National Renewable Energy Laboratory, 1617 Cole Blvel., Golden, CO 8(04)1

238. D. D. Woll, Virginia Tech, Dept. of Agronomy, Blacksburg, VA 24161

239. Office of Assistant Manager for Energy Rescarch and Development, Oak Ridge Operations, P.O. Box 2001, U.S. Department of Energy, Oak Ridge, TN 37831-86000

240-241. Office of Scientific and Technical Information, P.O. Box 62, Oak Ridge, TN 378.31 

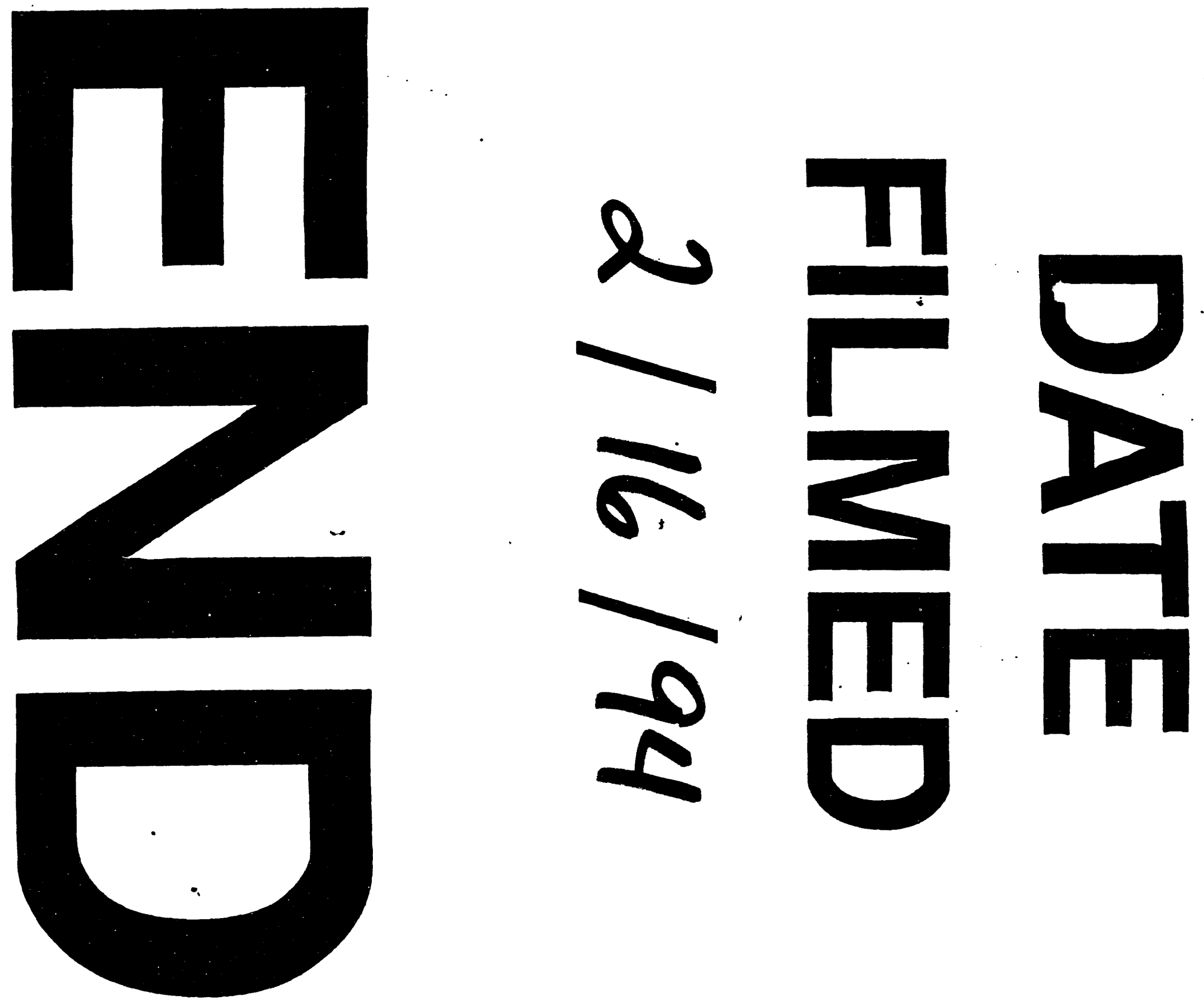
